\title{
Washing and Heat Treatment of Aluminum-Based Drinking Water Treatment Residuals to Optimize Phosphorus Sorption and Nitrogen Leaching: Considerations for Lake Restoration
}

\author{
Anthony C. Kuster ${ }^{1}\left(\mathbb{D}\right.$, Brian J. Huser ${ }^{2}{ }^{(}$, Surapol Padungthon ${ }^{3}\left(\mathbb{D}\right.$, Rittirong Junggoth $^{4}$ \\ and Anootnara T. Kuster $4, *$ (1) \\ 1 Faculty of Public Health, Khon Kaen University, Khon Kaen 40002, Thailand; akuster@kku.ac.th \\ 2 Department of Aquatic Sciences and Assessment, Swedish University of Agricultural Sciences, \\ 75007 Uppsala, Sweden; brian.huser@slu.se \\ 3 Department of Environmental Engineering, Khon Kaen University, Khon Kaen 40002, Thailand; \\ surapolp@kku.ac.th \\ 4 Department of Environmental Health and Occupational Health and Safety, Khon Kaen University, \\ Khon Kaen 40002, Thailand; rittirong@kku.ac.th \\ * Correspondence: anootta@kku.ac.th
}

check for

updates

Citation: Kuster, A.C.; Huser, B.J.; Padungthon, S.; Junggoth, R.; Kuster, A.T. Washing and Heat Treatment of Aluminum-Based Drinking Water Treatment Residuals to Optimize Phosphorus Sorption and Nitrogen Leaching: Considerations for Lake Restoration. Water 2021, 13, 2465. https://doi.org/10.3390/w13182465

Academic Editor: Changhui Wang

Received: 11 August 2021

Accepted: 6 September 2021

Published: 8 September 2021

Publisher's Note: MDPI stays neutral with regard to jurisdictional claims in published maps and institutional affiliations.

Copyright: (c) 2021 by the authors. Licensee MDPI, Basel, Switzerland. This article is an open access article distributed under the terms and conditions of the Creative Commons Attribution (CC BY) license (https:// creativecommons.org/licenses/by/ $4.0 /)$.

\begin{abstract}
Drinking water treatment residuals (DWTRs) generated during drinking water treatment have been proposed for use in lake restoration as a solid-phase sorbent to inactivate phosphorus $(\mathrm{P})$ in lake sediment. However, treatments that minimize leaching of nitrogen $(\mathrm{N})$ and optimize P sorption capacity may be necessary prior to use. This study assessed seven different treatment methods, including washing and heat treatments at different temperatures and with and without oxygen limitation, among two DWTRs from Thailand. Results showed that oxygen-limited heat treatment at $600{ }^{\circ} \mathrm{C}$ substantially reduced $\mathrm{N}$ leaching $(<0.2 \mathrm{mg} / \mathrm{kg}$ TKN) while also improving P sorption capacity (increase of $18-32 \%$ compared to untreated DWTR) to a maximum of $45.7 \mathrm{mg} \mathrm{P} / \mathrm{kg}$. Washing with deionized water reduced $\mathrm{N}$ leaching if a sufficient volume was used but did not improve P sorption. Heating at $200^{\circ} \mathrm{C}$ with or without the presence of oxygen did not improve $\mathrm{N}$ leaching or P sorption. Regression of $\mathrm{P}$ sorption parameters from a two-surface Langmuir isotherm against physio-chemical properties indicated that oxalate-extractable (i.e., amorphous) aluminum and iron were significantly associated with total $\mathrm{P}$ sorption capacity $\left(\mathrm{R}^{2}=0.94\right)$, but micropores and oxalate-extractable $\mathrm{P}$ modulated the $\mathrm{P}$ sorption from high-affinity to low-affinity mechanisms. In conclusion, this study confirmed the importance of amorphous aluminum in DWTRs for inactivating $\mathrm{P}$, and the results suggest that high-temperature treatment under oxygen-limited conditions may be the most reliable way to optimize DWTRs for environmental remediation applications.
\end{abstract}

Keywords: adsorption; alum sludge; binding efficiency; biochar; coagulant; eutrophication; oxidation; pyrolysis

\section{Introduction}

Anthropogenic eutrophication of freshwater lakes as a result of excessive nutrient loading has contributed to the global proliferation of harmful cyanobacterial blooms and deterioration of ecological health of surface waters [1]. Phosphorus (P) management is recognized as an essential strategy to reduce eutrophication and improve water quality [2], particularly as part of a dual nutrient management strategy [3]. One common geoengineering strategy for P management is the addition of solid-phase sorbents to lakes, which can be used to reduce dissolved $\mathrm{P}$ concentrations, target external $\mathrm{P}$ loading, and/or inactivate $\mathrm{P}$ in lake sediment in order to reduce internal P loading [4-6]. Several metal salts and modified clays have been used and studied for internal $P$ reduction in lakes [6]. The most commonly used solid-phase sorbents for P immobilization in lakes are aluminum (Al) salts, including aluminum sulfate (alum), polyaluminum chloride (PAC), and aluminum chloride $\left(\mathrm{AlCl}_{3}\right)$, 
having been applied to many hundreds of lakes worldwide [7]. While in-lake application of $\mathrm{Al}$ salts can be the most cost-effective measure to address eutrophication in lakes [8], limitations to the use of $\mathrm{Al}$ salts have been identified, including the possibility for transient toxicity to freshwater organisms from newly formed amorphous Al hydroxide [9] and reduced $\mathrm{P}$ adsorption effectiveness due to competing compounds [10] or crystalline aging of the newly formed, amorphous mineral [11]. Other P sorbents, such as iron (Fe) salts and lanthanum modified bentonites (LMBs), are limited by narrow physio-chemical conditions and cost, respectively $[12,13]$. Therefore, the development of new and alternative $P$ immobilizing materials is still needed [14].

Drinking water treatment residual (DWTR) is the sludge byproduct generated in the flocculation and sedimentation unit processes of drinking water treatment production and is commonly landfilled as a waste product [15]. Because water treatment plants (WTPs) commonly use Al salts as coagulants, the DWTRs generated from WTPs often contain high amounts of $\mathrm{Al}$ hydroxides $\left(\mathrm{Al}(\mathrm{OH})_{\mathrm{x}}\right)$ and $\mathrm{Al}$ ions [16,17], which are effective at adsorbing metals, metalloids, and organic compounds [18]. In particular, the Al hydroxides in DWTRs are effective at adsorbing $\mathrm{P}$ in the form of ortho- and polyphosphates [19]. The high $\mathrm{P}$ sorption capacity of DWTRs has been extensively documented $[16,17,20]$ and is primarily associated with the amorphous Al and Fe content in the DWTR [21,22]. Due to these characteristics, much research has gone into evaluating reuses for DWTR to control P in the environment, including application as a soil amendment to reduce nutrient runoff [23] and as a soil substrate in constructed wetlands to treat wastewater and runoff $[24,25]$. DWTR has also been identified as a possible candidate for in situ application to lakes for sediment $P$ inactivation $[26,27]$.

However, DWTR contains substantial quantities of organic matter, including organic nitrogen $(\mathrm{N})$ and $\mathrm{P}$ [28]. The $\mathrm{N}$ in recycled DWTR has been shown to release or desorb [29] when DWTR is used as a substrate for treating wastewater [30], in fixed-column treatment of eutrophic surface water [31], and for sediment capping [26]. In response, several pretreatment solutions have been proposed to reduce the release of N from DWTR, including oxygen-limited heat treatment [32,33], intermittent aeration [28], aging [34], washing [29], and various granulation methods [35]. However, many of these methods can be energy and resource intensive, limiting the feasibility and sustainability of DWTR as a recycled product. Additionally, these treatment methods have not been heretofore compared directly against each other but only against untreated DWTR. Therefore, it is important to isolate the effects of these treatments on $\mathrm{N}$ desorption and subsequent effects on $\mathrm{P}$ sorption capacity in order to optimize the process and elucidate the underlying mechanisms enacting changes in the characteristics of the DWTR. Furthermore, DWTR is highly variable in its composition $[17,36]$. The raw water source, coagulant used, and dewatering technique can affect DWTR properties [37,38]. Finally, the study of recycled DWTR for lake restoration purposes remains very limited in tropical environments.

Therefore, the purpose of this study was to identify an optimized treatment method of DWTR that achieved low $\mathrm{N}$ desorption and high $\mathrm{P}$ sorption for application in lake restoration using several DWTRs collected in tropical Thailand. The specific objectives were to: (1) generate and characterize several DWTRs using a variety of treatment methods; (2) assess the effect of the treatment methods on $\mathrm{N}$ desorption and $\mathrm{P}$ sorption; and (3) identify properties associated with P sorption capacity and, thus, provide recommendations for treatment of DWTR for use in lake restoration applications.

\section{Materials and Methods}

\subsection{Collection and Preparation of DWTRs}

The DWTRs used in these experiments was collected from four different WTPs that supply domestic water to municipalities in northeast Thailand, identified by two-letter abbreviations as BP, MS, DP, and UD. The WTPs produce between 14,400 and $48,000 \mathrm{~m}^{3} /$ day of drinking water; use raw water supplied from a river, lake, or reservoir; and use PAC, alum, or a combination of PAC and alum as coagulants in treatment (Table 1). 
Table 1. Characteristics of water treatment plants (WTPs) from which DWTR was sampled.

\begin{tabular}{cccc}
\hline WTP Abbreviation & $\begin{array}{c}\text { Water Supply } \\
\left.\text { Capacity } \mathbf{( m}^{\mathbf{3}} \mathbf{h} \mathbf{h}\right)\end{array}$ & Raw Water Source & Coagulant Used \\
\hline BP & 14,400 & Lawa Lake & PAC/Alum \\
MS & 30,800 & Chee River & PAC/Alum \\
DP & 32,000 & Chee River & PAC \\
UD & 48,000 & Huai Luang Reservoir & Alum \\
\hline
\end{tabular}

Raw DWTR was collected directly from the sedimentation tanks during regular maintenance from several different locations in the tank and then composited into plastic containers for transport back to the laboratory, where the samples were stored in a refrigerator $\left(4^{\circ} \mathrm{C}\right)$. Within 28 days, the composite samples were homogenized and then oven dried at $105^{\circ} \mathrm{C}$ for $48 \mathrm{~h}$ to dewater the DWTR. The dewatered DWTR was ground and sieved to $<150 \mu \mathrm{m}$ (sieve \#100).

\subsection{Experimental Treatment of DWTRs}

Two of the four prepared DWTRs (DP, UD) were studied for how treatment methods affect the physiochemical characteristics, P sorption capacity, and leachability of $\mathrm{N}$. Seven experimental treatments were assessed (Table 2). Washing was completed by adding dried DWTR to a glass beaker and mixing deionized water at a $1: 10 \mathrm{~m} / \mathrm{v}$ ratio using a glass rod for $5 \mathrm{~min}$, leaving it stagnant for 3-6 h, siphoning off the supernatant, and then drying the washed DWTR for $48 \mathrm{~h}$ at $105^{\circ} \mathrm{C}$. A higher 1:20 m/v ratio was used in the multi-washing. Heat treatment was completed using a muffle furnace without covering the crucibles containing the dried DWTR. Oxygen-limited treatment was completed using a muffle furnace (ISOLAB Laborgeräte $\mathrm{GmbH}$, Eschau, Germany) under a $\mathrm{N}_{2}$ atmosphere while covering the crucible. Following each treatment, the treated DWTR was ground and sieved to $<150 \mu \mathrm{m}$, similar to the prepared (untreated) DWTR.

Table 2. Summary of experimental treatments of DWTRs and corresponding abbreviations.

\begin{tabular}{|c|c|c|c|}
\hline Treatment Name & Abbreviation & Experimental Treatment & $\begin{array}{l}\text { Approximate } \\
\text { Yield }^{1}\end{array}$ \\
\hline Single washing & $\mathrm{W}$ & $\begin{array}{l}\text { washing } 1 \mathrm{x} \text { with deionized water }(1: 10 \\
\mathrm{m} / \mathrm{v}) \text { and then dried for } 48 \mathrm{~h} \text { at } 105^{\circ} \mathrm{C}\end{array}$ & $97-99 \%$ \\
\hline Multi-washing & MW & $\begin{array}{l}\text { washing } 3 \mathrm{x} \text { with deionized water }(1: 20 \\
\mathrm{m} / \mathrm{v}) \text { and then dried for } 48 \mathrm{~h} \text { at } 105^{\circ} \mathrm{C}\end{array}$ & $95-99 \%$ \\
\hline Heat treatment at $200^{\circ} \mathrm{C}$ & 200 & heated to $200^{\circ} \mathrm{C}$ for $2 \mathrm{~h}$ in muffle furnace & $90-95 \%$ \\
\hline Heat treatment at $600{ }^{\circ} \mathrm{C}$ & 600 & heated to $600{ }^{\circ} \mathrm{C}$ for $2 \mathrm{~h}$ in muffle furnace & $60-85 \%$ \\
\hline $\begin{array}{l}\text { Oxygen-limited heat } \\
\text { treatment at } 200{ }^{\circ} \mathrm{C}\end{array}$ & OL200 & $\begin{array}{l}\text { heated to } 200^{\circ} \mathrm{C} \text { for } 2 \mathrm{~h} \text { in muffle furnace } \\
\text { with } \mathrm{N}_{2} \text { atmosphere }\end{array}$ & $90-95 \%$ \\
\hline $\begin{array}{l}\text { Oxygen-limited heat } \\
\text { treatment at } 600{ }^{\circ} \mathrm{C}\end{array}$ & OL600 & $\begin{array}{l}\text { heated to } 600^{\circ} \mathrm{C} \text { for } 2 \mathrm{~h} \text { in muffle furnace } \\
\text { with } \mathrm{N}_{2} \text { atmosphere }\end{array}$ & $60-85 \%$ \\
\hline $\begin{array}{l}\text { Multi-washing and } \\
\text { oxygen-limited heat } \\
\text { treatment at } 600{ }^{\circ} \mathrm{C}\end{array}$ & MW600 & $\begin{array}{l}\text { Multi-washing followed by } \\
\text { oxygen-limited treatment at } 600{ }^{\circ} \mathrm{C}\end{array}$ & $55-80 \%$ \\
\hline
\end{tabular}

\subsection{Leaching Assays}

To determine the affinity of $\mathrm{N}$ to leach from the DWTRs, samples were mixed with deionized water at a 1:20 m/v ratio and shaken on an orbital shaker at $200 \mathrm{rpm}$ for $6 \mathrm{~h}$ at room temperature $\left(23^{\circ} \mathrm{C}\right)$ [26]. The suspension was centrifuged at $500 \times g$ for $10 \mathrm{~min}$, 
decanted, and filtered through a $0.45-\mu \mathrm{m}$ fiber filter. The filtered water was analyzed for ammonia $\left(\mathrm{NH}_{3}-\mathrm{N}\right)$, TKN, nitrate $\left(\mathrm{NO}_{3}-\mathrm{N}\right)$, and nitrite $\left(\mathrm{NO}_{2}-\mathrm{N}\right)$ using the Kjeldahl method with mercury as a catalyst. Organic N (TKN less ammonia) and total N (sum of TKN, $\mathrm{NO}_{3}-\mathrm{N}$, and $\mathrm{NO}_{2}-\mathrm{N}$ ) were computed from the analyses.

\subsection{Physio-Chemical Characterization of DWTRs}

Prepared and treated DWTRs were characterized for several physio-chemical properties. They were analyzed for metals using inductively coupled plasma optical emission spectrometry (ICP-OES) (EPA Method 3050B). According to the procedure, $0.1 \mathrm{~g}$ of dry sediment were digested using $3 \mathrm{~mL}$ of nitric acid $\left(\mathrm{HNO}_{3}\right)$ and $3 \mathrm{~mL}$ of perchloric acid and then analyzed using ICP-OES. The following metals were analyzed: $\mathrm{Al}, \mathrm{Ca}, \mathrm{Fe}, \mathrm{Mg}, \mathrm{Mn}$, and $\mathrm{Zn}$. Total $\mathrm{N}$ and total $\mathrm{P}$ were determined using the Dumas method with dry combustion [39] and ICP-OES following microwave digestion (EPA Method 3052), respectively. The Brunauer-Emmett-Teller (BET) adsorption/desorption method using nitrogen $\left(\mathrm{N}_{2}\right)$ at $77 \mathrm{~K}$ with a relative pressure $\left(\mathrm{P} / \mathrm{P}_{0}\right)$ range from 0 to 1 (QUADRASORB evo Gas Sorption Surface Area and Pore Size Analyzer, Anton Paar, Graz, Austria) was used to assess the physical adsorption of the DWTRs. From this data, the QUARASORB software was able to compute the total pore volume at $\mathrm{P} / \mathrm{P}_{0}=0.98$, Langmuir specific surface area (SSA), BarretJoyner-Halenda (BJH) cumulative adsorption pore volume (PV), Horvath-Kawazoe (HK) micropore volume, and average pore radius. Particle size distribution was determined by measuring the diameters of particles that were randomly selected from an image of each DWTR specimen developed using scanning electron microscopy (SEM) (JEOL JSM-6010LA, Tokyo, Japan). SEM samples were prepared with osmium tetroxide $1 \%$ aqueous solution and sputter-coated with gold. Five parameters characterizing the size distribution of DWTR were computed from the size distribution data, namely the 10th percentile diameter, $\mathrm{D}_{10}$; 30 th percentile diameter, $\mathrm{D}_{30}$; 60th percentile diameter, $\mathrm{D}_{60}$; coefficient of uniformity, $\mathrm{C}_{\mathrm{u}}$; and coefficient of curvature, $\mathrm{C}_{\mathrm{c}}$ [40]. The concentrations of oxalate-extractable $\mathrm{Fe}, \mathrm{Al}$, and $\mathrm{P}\left(\mathrm{Fe}_{\mathrm{ox}}, \mathrm{Al}_{\mathrm{ox}}\right.$, and $\mathrm{P}_{\mathrm{ox}}$, respectively) were determined by extracting with ammonium oxalate and oxalic acid. The extraction was performed with a buffered solution of $0.2 \mathrm{M}$ ammonium oxalate $\left[\left(\mathrm{NH}_{4}\right)_{2} \mathrm{C}_{2} \mathrm{O}_{4}\right]$ and $0.2 \mathrm{M}$ oxalic acid $\left(\mathrm{H}_{2} \mathrm{C}_{2} \mathrm{O}_{4}\right)$ adjusted to $\mathrm{pH} 3$ at a $100: 1 \mathrm{~m} / \mathrm{v}$ ratio using an orbital shaker for $4 \mathrm{~h} \mathrm{[20].} \mathrm{Following} \mathrm{extraction,} \mathrm{the} \mathrm{samples}$ were analyzed for $\mathrm{Al}, \mathrm{Fe}$, and $\mathrm{P}$ using ICP-OES. Oxalate-extractable $\mathrm{Fe}$ and $\mathrm{Al}$ represent amorphous (non-crystalline) forms of $\mathrm{Fe}$ and $\mathrm{Al}$ [41]; however, the chemicals may also extract some crystalline forms of the metals [42].

\subsection{Phosphorus Sorption Capacity and Isotherms}

The P sorption capacity of materials is commonly determined using batch experiments; however, the particle size, material-to-solution ratio, initial $\mathrm{P}$ concentration, contact time, agitation method, and method for determining maximum capacity can be highly variable across studies, with each variation having some effect on the estimate of sorption capacity [43]. In this study, $50 \mathrm{mg}$ of dried DWTR were equilibrated with $10 \mathrm{~mL}$ of $\mathrm{P}$ solutions at nine concentrations $(0,1,5,10,20,50,100,200$, and $300 \mathrm{mg} \mathrm{P} / \mathrm{L})$ created from $\mathrm{H}_{2} \mathrm{PO}_{4}$ standard solution, while kept in the dark for 30 days and shaken by hand once per day. After 30 days, the tubes were centrifuged at $500 \times g$ for $10 \mathrm{~min}$. Each batch was conducted in triplicate. The amount of $\mathrm{P}$ sorbed was determined as the reduction in $\mathrm{P}$ following the conclusion of the batch experiment, with P measured using ascorbic acid colorimetric spectrophotometry.

Since adsorption cannot be distinguished in these tests from other mechanisms, the term sorption was used here to refer to all $\mathrm{P}$ retention mechanisms collectively [44]. The P sorption capacity of DWTRs was determined using a nonlinear two-surface Langmuir isotherm [45] with a modification to account for native P desorption [46]. Equation (1):

$$
Q=\frac{b_{1} K_{1} C}{1+K_{1} C}+\frac{b_{2} K_{2} C}{1+K_{2} C}-\left(\frac{b_{1} K_{1} C_{0}}{1+K_{1} C_{0}}+\frac{b_{2} K_{2} C_{0}}{1+K_{2} C_{0}}+\frac{C_{0} V_{0}}{m_{0}}\right)
$$


where $Q$ is the amount of $\mathrm{P}$ sorbed according to the modified two-surface Langmuir equation, $C$ is the aqueous concentration of $\mathrm{P}$ following equilibrium; $b_{1}$ and $b_{2}$ are the highand low-affinity P sorption capacities; $K_{1}$ and $K_{2}$ are constants related to the high- and lowaffinity binding energies of $P$ sorption; and $C_{0}, V_{0}$, and $m_{0}$ are the aqueous concentration of $P$ following equilibrium, aqueous solution volume, and mass of DWTR added in the batch in which zero $P$ was added, respectively.

The values for parameters $b_{1}, b_{2}, K_{1}$, and $K_{2}$ were determined by minimizing the sum of the squares of the residuals, using the generalized reduced gradient solver within a Microsoft Excel spreadsheet [47]. The Nash-Sutcliffe model efficiency measure, E, was also computed [48].

\subsection{Statistical Analysis}

The P saturation index (PSI) was computed from oxalate extraction data [20] using Equation (2):

$$
\text { PSI }=\frac{\mathrm{P}_{\mathrm{ox}}}{\mathrm{Al}_{\mathrm{ox}}+\mathrm{Fe}_{\mathrm{ox}}}
$$

where $\mathrm{P}_{\mathrm{ox}}, \mathrm{Al}_{\mathrm{ox}}$, and $\mathrm{Fe}_{\mathrm{ox}}$ were the oxalate-extractable $\mathrm{P}, \mathrm{Al}$, and $\mathrm{Fe}$.

To determine which physio-chemical properties were associated with the P sorption outcomes $\left(b, b_{1}, b_{2}, K_{1}, K_{2}\right)$, each $\mathrm{P}$ sorption outcome was independently regressed against physio-chemical parameter values. Potential factors considered included $\mathrm{Al}, \mathrm{Fe}, \mathrm{Al}_{\mathrm{ox}}, \mathrm{Fe}_{\mathrm{ox}}$, $\mathrm{P}_{\mathrm{ox}}, \mathrm{PSI}$, calcium (Ca), total P, Langmuir SSA, BJH cumulative adsorption PV, HK micropore volume, average pore radius, $\mathrm{D}_{30}$, and $\mathrm{D}_{60}$. First, visual inspection was used to identify non-linear relationships, and log transformation was used if necessary. Next, Pearson's product-moment correlation was computed for all variables. Variables that correlated $(p<0.20)$ with the P sorption outcome were included in an initial multiple linear regression (MLR) model for that outcome (5 total MLR models). Backwards stepwise methods were used to remove independent variables until the final MLR model included only significant factors (significance level, $\alpha=0.05$ ).

\section{Results}

\subsection{Metal and Nutrient Content}

Despite differences in the initial contents in the two raw DWTRs (Supplementary Materials Table S1), the experimental treatments had relatively consistent effects on the contents of metals and nutrients (Figure 1). The metals $\mathrm{Al}, \mathrm{Fe}, \mathrm{Mn}$, and $\mathrm{Zn}$ generally increased in concentration following treatment, with greater increases occurring at higher treatment temperatures. For this group of metals, washing had minimal effects on the contents. Therefore, these compounds were relatively stable, and the changes observed in heat treatments were likely the result of a concentrating effect as other compounds were removed during treatment.

A second group of metals, however, consisted of $\mathrm{Ca}$ and $\mathrm{Mg}$, which are commonly divalent. While their concentrations also increased from oxygen-limited heat treatments (i.e., pyrolysis), they decreased as a result of non-oxygen-limited (i.e., oxidation) heat treatments (200 and 600) and single washing treatment (W). These minerals are important to organic material and may have been associated with organic material that was combusted during oxidation or associated with fine particles mobilized and removed during washing. The data for total $\mathrm{P}$ followed the same trend, suggesting changes in $\mathrm{Mg}$ and Ca were associated with P. When oxygen-limited heat treatments were used, the $\mathrm{Ca}$ and $\mathrm{Mg}$ contents increased, despite the decreases observed at equivalent temperatures when oxygen was not limited (Figure 1). 


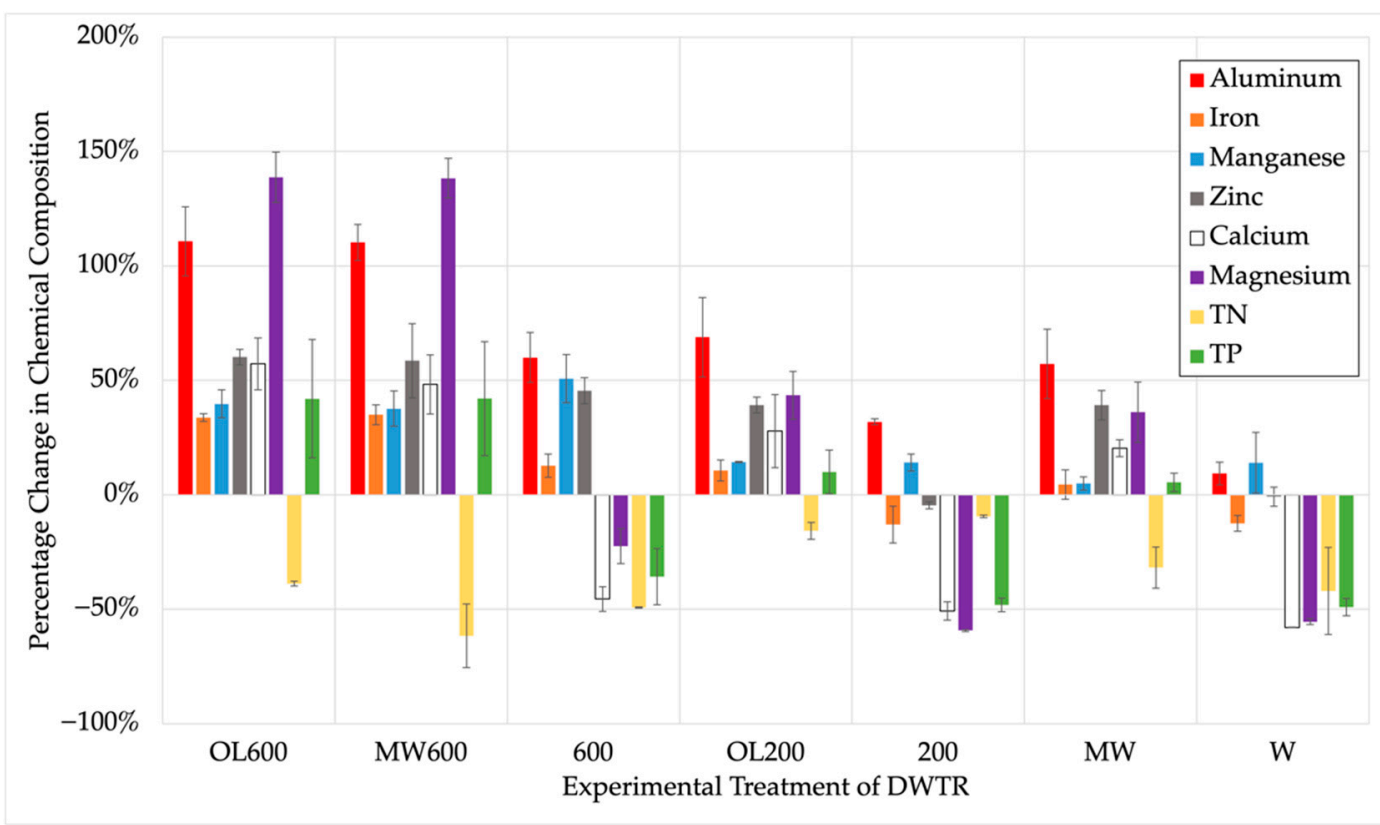

Figure 1. Average relative change (percentage) in concentration of metals and nutrients of two experimentally treated DWTRs (DP, UD) with bars representing the range in the average of the individual DWTR. Descriptions of treatments with abbreviations provided in Table 2.

Generally, every treatment reduced total $\mathrm{N}$. The reduction of total $\mathrm{N}$ ranged from 10 to $80 \%$, depending on the treatment. However, the high-temperature oxygen-limited heat treatments (i.e., OL600 and MW600) removed significant non-nutrient mass (as indicated by the increased metals content), which masked the overall reduction in total $\mathrm{N}$ due to the reduction of the overall mass of the material. Organic $\mathrm{N}$ was abundant in the leachate water generated during washing (Supplementary Materials Table S2), indicating that washing mobilized fine particles containing organic N from the DWTR.

While the $\mathrm{Al}$ and Fe contents are generally important for $\mathrm{P}$ adsorption, adsorption is specifically related to the amount of $\mathrm{Al}$ and $\mathrm{Fe}$ that is in an amorphous (i.e., non-crystalline) form, as measured by $\mathrm{Al}_{\mathrm{ox}}$ and $\mathrm{Fe}_{\mathrm{ox}}$ [20]. Overall, each of the DWTRs in raw and treated forms contained higher amounts of $\mathrm{Al}_{\mathrm{ox}}$ compared to $\mathrm{Fe}_{\mathrm{ox}}$, which can be expected because all four WTPs used Al-based coagulants (Figure 2). The total amount of $\mathrm{Al}_{\mathrm{ox}}$ and $\mathrm{Fe}_{\mathrm{ox}}$ in the raw DWTR collected from DP was lower than the raw DWTR from UD, which was likely due to the type and amount of coagulant used. The UD WTP used alum (as opposed to PAC) and had higher turbidity, requiring higher coagulant doses. The results also showed that oxygen-limited heat treatments of $600^{\circ} \mathrm{C}$ increased the contents of $\mathrm{Al}_{\mathrm{ox}}$ and $\mathrm{Fe}_{\mathrm{ox}}$ in both DWTRs (Figure 2). On the other hand, washing and non-oxygen-limited heat treatments had no effect or marginally reduced the concentrations of $\mathrm{Al}_{\mathrm{ox}}$ and $\mathrm{Fe}_{\mathrm{ox}}$.

\subsection{Nitrogen Gas Sorption/Desorption}

The $\mathrm{N}_{2}$ adsorption/desorption isotherms indicated that the DP DWTRs (Figure 3a) had higher overall pore space as compared to the UD DWTRs (Figure $3 b$ ). The maximum volume of $\mathrm{N}_{2}$ that adsorbed to DP-OL600 and DP-MW was 187 and $182 \mathrm{~cm}^{3} / \mathrm{g}$, respectively, whereas the maximum volume of $\mathrm{N}_{2}$ that adsorbed to UD-OL600, UD-MW600, and UDMW was 150,150, and $148 \mathrm{~cm}^{3} / \mathrm{g}$, respectively. Comparing the shapes of the isotherms between DP and UD, however, showed that overall porosity was distributed in different pore sizes, indicating different structures of the two materials. The shapes of the DP isotherms indicated that most of the pore space was macroporous $\left(\mathrm{P} / \mathrm{P}_{0}>0.8\right)$. On the other hand, the higher volume of $\mathrm{N}_{2}$ adsorbed at low relative pressures $\left(\mathrm{P} / \mathrm{P}_{0}<0.1\right)$ in the UD DWTRs indicated the presence of micropores [49]. The data reduction parameters derived from the $\mathrm{BJH}$ and $\mathrm{HK}$ models quantified these observations. The HK micropore 
volumes in the UD DWTRs ranged from 0.031 to $0.069 \mathrm{~cm}^{3} / \mathrm{g}$ but from 0.020 to $0.032 \mathrm{~cm}^{3} / \mathrm{g}$ in the DP DWTRs (Table 3).

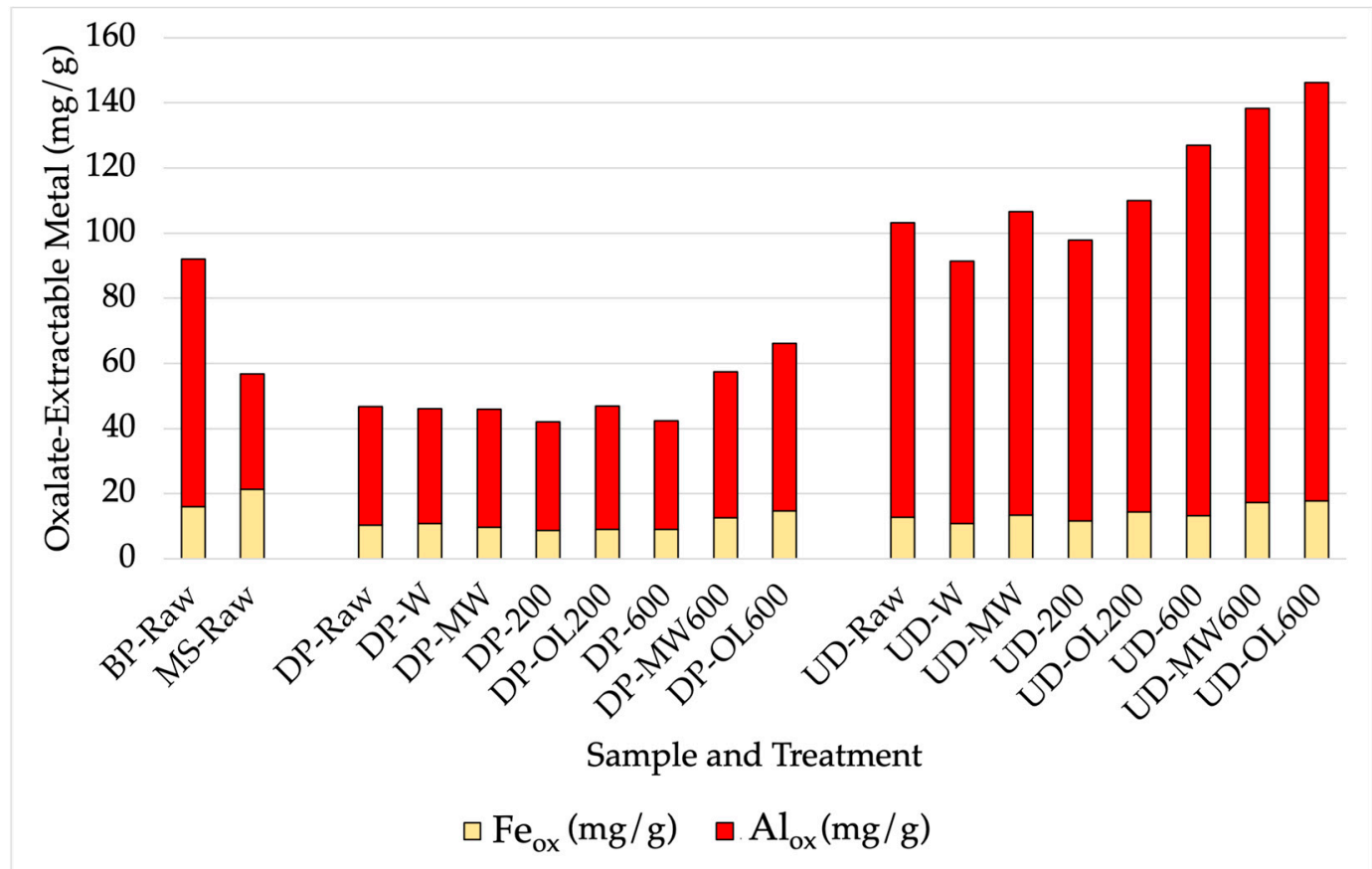

Figure 2. Concentration of oxalate-extractable $\mathrm{Al}\left(\mathrm{Al}_{\mathrm{ox}}\right)$ and $\mathrm{Fe}\left(\mathrm{Fe}_{\mathrm{ox}}\right)$ in the raw and experimentally treated DWTRs.

Table 3. Physiochemical data reduction parameters from BET adsorption/desorption tests with $\mathrm{N}_{2}$.

\begin{tabular}{|c|c|c|c|c|}
\hline DWTR Sample Name & Langmuir SSA (m²/g) & $\begin{array}{c}\text { BJH Cumulative } \\
\text { Adsorption SSA }\left(\mathrm{m}^{2} / \mathrm{g}\right)\end{array}$ & $\begin{array}{l}\text { HK Micropore } \\
\text { Volume }\left(\mathrm{cm}^{3} / \mathrm{g}\right)\end{array}$ & $\begin{array}{c}\text { Average Pore } \\
\text { Radius (Å) }\end{array}$ \\
\hline $\mathrm{BP}$ & 212.3 & 36.4 & 0.0328 & 45.8 \\
\hline MS & 158.8 & 28.4 & 0.0240 & 52.3 \\
\hline $\mathrm{DP}$ & 204.8 & 39.4 & 0.0285 & 71.1 \\
\hline $\mathrm{DP}-\mathrm{W}$ & 194.0 & 38.5 & 0.0237 & 73.7 \\
\hline DP-MW & 234.5 & 44.8 & 0.0316 & 73.8 \\
\hline DP-200 & 207.0 & 43.3 & 0.0255 & 69.3 \\
\hline DP-OL200 & 270.3 & 50.5 & 0.0314 & 63.1 \\
\hline DP-600 & 180.4 & 39.6 & 0.0198 & 91.4 \\
\hline DP-OL600 & 179.6 & 43.9 & 0.0226 & 105.8 \\
\hline DP-MW600 & 183.5 & 40.1 & 0.0232 & 88.0 \\
\hline UD & 311.6 & 45.1 & 0.0513 & 36.0 \\
\hline UD-W & 188.9 & 32.9 & 0.0392 & 37.9 \\
\hline UD-MW & 359.6 & 45.6 & 0.0685 & 29.0 \\
\hline UD-200 & 259.7 & 40.0 & 0.0452 & 34.4 \\
\hline UD-OL200 & 254.2 & 41.9 & 0.0352 & 40.0 \\
\hline UD-600 & 171.9 & 39.2 & 0.0310 & 55.0 \\
\hline UD-OL600 & 346.4 & 59.6 & 0.0481 & 39.7 \\
\hline UD-MW600 & 342.5 & 63.4 & 0.0433 & 43.7 \\
\hline
\end{tabular}




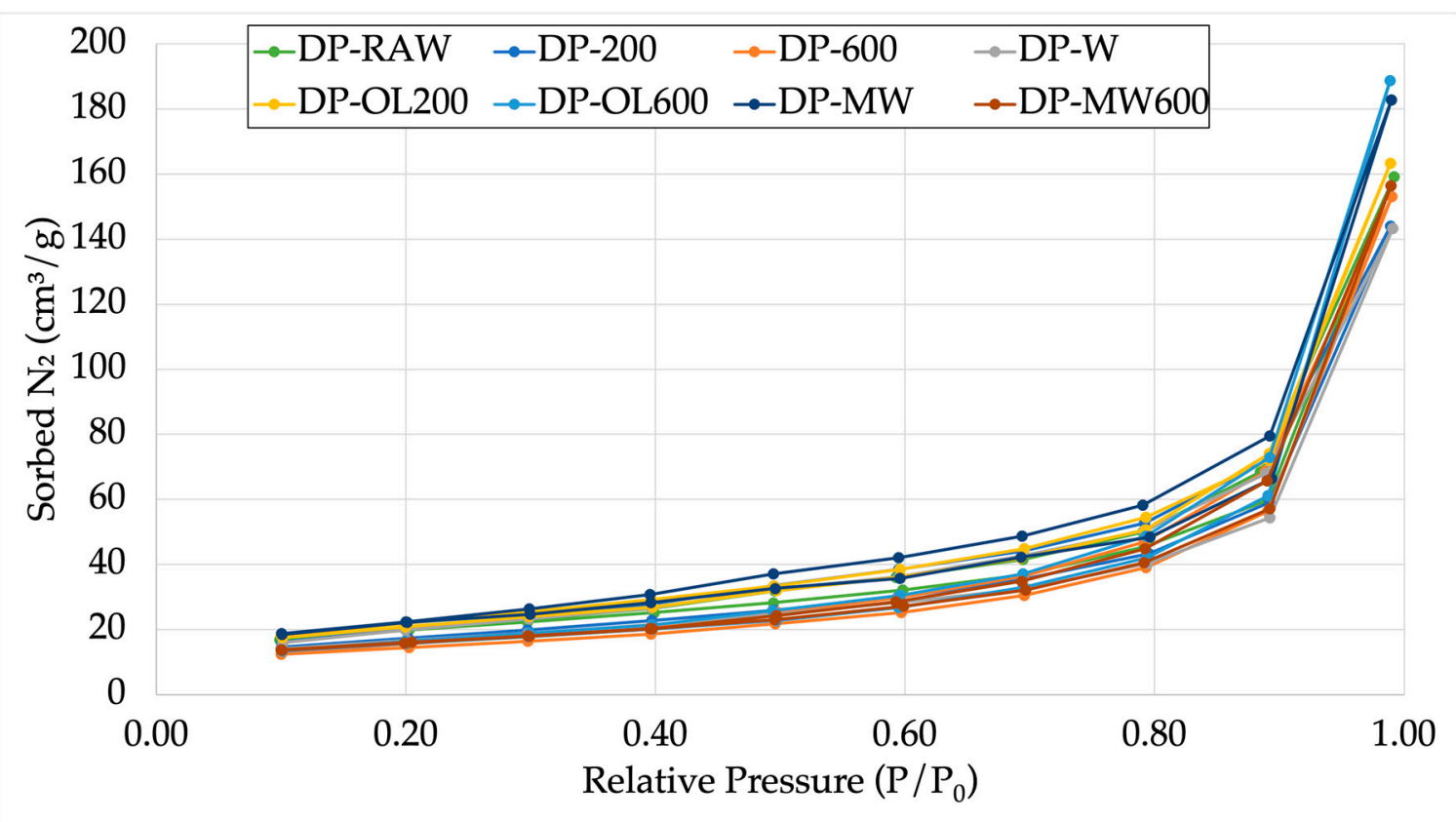

(a)

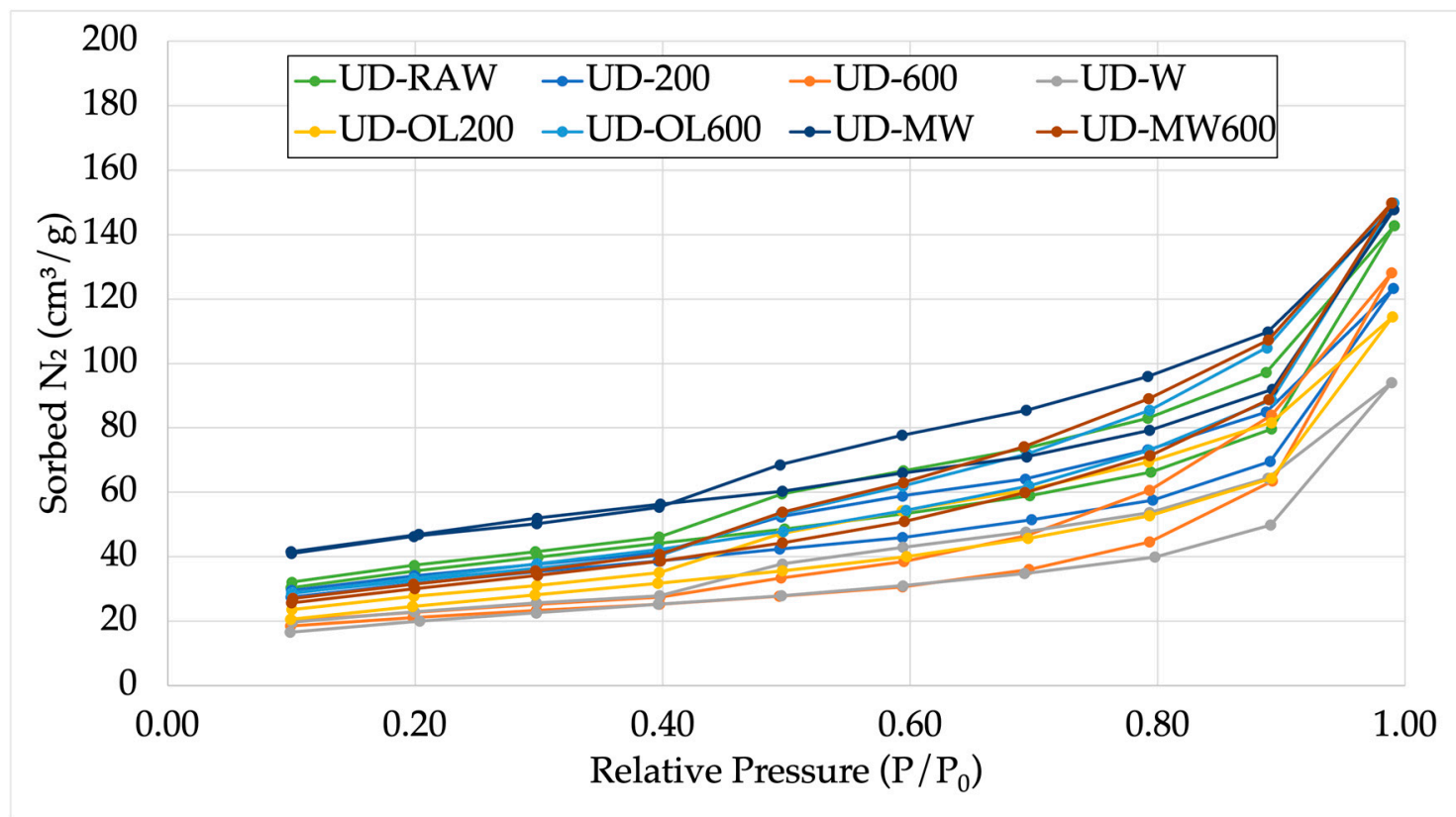

(b)

Figure 3. $\mathrm{N}_{2}$ gas adsorption/desorption isotherms: (a) of one raw and seven experimental treatments of the DP DWTR; (b) of one raw and seven experimental treatments of the UD DWTR.

The adsorption/desorption isotherms for the DP DWTRs (Figure 3a) could be classified as reversible type II isotherms [50]. The isotherms indicated that the DP DWTRs were nonporous powders. On the other hand, the isotherms for the UD DWTRs (Figure 3b) could be classified as type II isotherms with type H3 hysteresis loops [50]. These hysteresis loops indicated some interconnected pores with narrow bottlenecks.

Generally, the experimental treatments did not substantially change the shape of the isotherms, indicating the material did not change form during treatment. However, the amount and distribution of pore spaces was affected by treatment. Single washing (W) 
created the lowest $\mathrm{N}_{2}$ adsorption volumes in the DWTRs from both DP and UD, suggesting the washing treatment filled voids and reduced porosity. In both the DP and UD DTWRs, the multi-washing treatment increased micropores, as indicated by the high adsorption volume at low relative pressures and higher HK micropore volumes (Table 3). Oxygen-limited heat treatments at $600{ }^{\circ} \mathrm{C}$ increased the pore volume.

\subsection{P Sorption Capacity}

The DWTRs had a high affinity to sorb $\mathrm{P}$ based on the results of the $\mathrm{P}$ sorption batch experiments (Figure 4). The two DWTRs from this study that were experimentally treated had the lowest (DP) and highest (UD) P sorption capacities among the four raw DWTRs (Figure 4a). Treatments caused minimal changes in the P sorption isotherms of the DWTR from DP (Figure $4 \mathrm{~b}$ ). On the other hand, more substantial changes in the P sorption isotherms occurred as a result of experimental treatments in the DWTR from UD (Figure 4c). Relative to the raw form, the low-temperature treatments (OL200 and 200) and washing (MW and W) slightly reduced the P sorption capacity of the UD DWTR, while the other treatments that included higher temperatures increased the P sorption capacity of the DWTR.

The two-surface Langmuir isotherm described the P sorption data well. The NashSutcliffe efficiency metric, E, ranged from 0.993 to 0.999 (Table 4). From the two-surface Langmuir isotherms, the total $\mathrm{P}$ sorption capacity could be characterized as being comprised of two different components, which were identified by $b_{1}$ and $b_{2}$. The high-affinity $\mathrm{P}$ sorption, represented by parameter $b_{1}$, was increased by high-temperature treatments. On the other hand, the low-affinity P sorption $\left(b_{2}\right)$ was higher than $b_{1}$ and was less variable across treatments. The binding energy constant for the high-affinity sorption, $K_{1}$, was also affected by the treatment. The high-temperature treatments appeared to increase the binding energy constant. The binding energy constant for low-affinity P sorption $\left(K_{2}\right)$, however, remained relatively constant across all samples and treatments.

Table 4. Phosphorus sorption capacities and binding energy constants derived from two-surface Langmuir isotherms.

\begin{tabular}{|c|c|c|c|c|c|c|}
\hline Sample & $b_{1}$ & $b_{2}$ & $\begin{array}{c}\text { P Sorption } \\
\text { Capacity, } b^{1}\end{array}$ & $\mathbf{K}_{1}$ & $\mathbf{K}_{2}$ & $\mathbf{E}$ \\
\hline BP-Raw & 8.21 & 25.84 & 34.05 & 19.97 & 0.0190 & 0.998 \\
\hline MS-Raw & 5.99 & 21.58 & 27.57 & 7.92 & 0.0136 & 0.999 \\
\hline DP-Raw & 3.64 & 15.87 & 19.51 & 13.95 & 0.0202 & 0.998 \\
\hline DP-W & 3.14 & 17.63 & 20.77 & 10.44 & 0.0180 & 0.999 \\
\hline DP-MW & 2.90 & 19.01 & 21.91 & 12.24 & 0.0122 & $>0.999$ \\
\hline DP-200 & 4.32 & 16.94 & 21.26 & 19.17 & 0.0197 & 0.998 \\
\hline DP-OL200 & 3.79 & 18.82 & 22.61 & 29.15 & 0.0194 & 0.999 \\
\hline DP-600 & 4.29 & 17.48 & 21.77 & 44.46 & 0.0199 & 0.999 \\
\hline DP-OL600 & 4.48 & 21.45 & 25.93 & 86.50 & 0.0108 & 0.997 \\
\hline DP-MW600 & 4.75 & 18.30 & 23.05 & 132.03 & 0.0166 & 0.999 \\
\hline UD-Raw & 8.74 & 27.86 & 36.60 & 50.14 & 0.0241 & 0.993 \\
\hline UD-W & 8.28 & 27.28 & 35.56 & 14.62 & 0.0135 & 0.999 \\
\hline UD-MW & 7.87 & 27.56 & 35.43 & 18.47 & 0.0155 & 0.998 \\
\hline UD-200 & 11.11 & 22.99 & 34.10 & 30.94 & 0.0173 & 0.999 \\
\hline UD-OL200 & 9.04 & 22.47 & 31.51 & 95.76 & 0.0231 & 0.998 \\
\hline UD-600 & 16.91 & 23.70 & 40.61 & 107.60 & 0.0176 & 0.999 \\
\hline UD-OL600 & 22.00 & 23.69 & 45.69 & 164.23 & 0.0214 & 0.998 \\
\hline UD-MW600 & 18.11 & 27.18 & 45.29 & 102.06 & 0.0134 & 0.997 \\
\hline Min & 2.90 & 15.87 & 19.51 & 7.92 & 0.0108 & 0.993 \\
\hline Max & 22.00 & 27.86 & 45.69 & 164.23 & 0.0241 & $>0.999$ \\
\hline
\end{tabular}




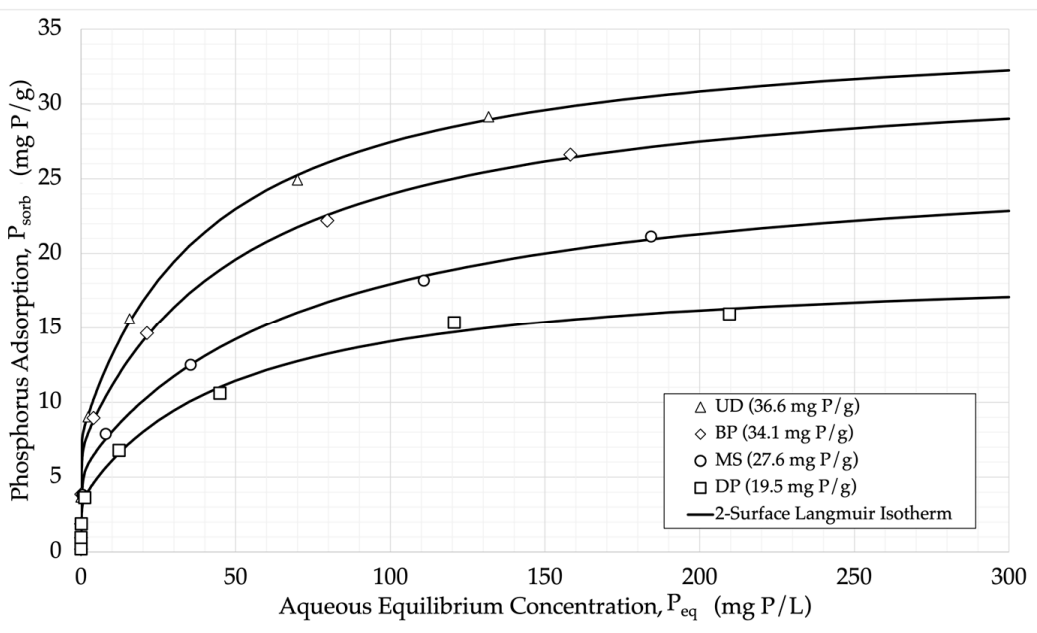

(a)

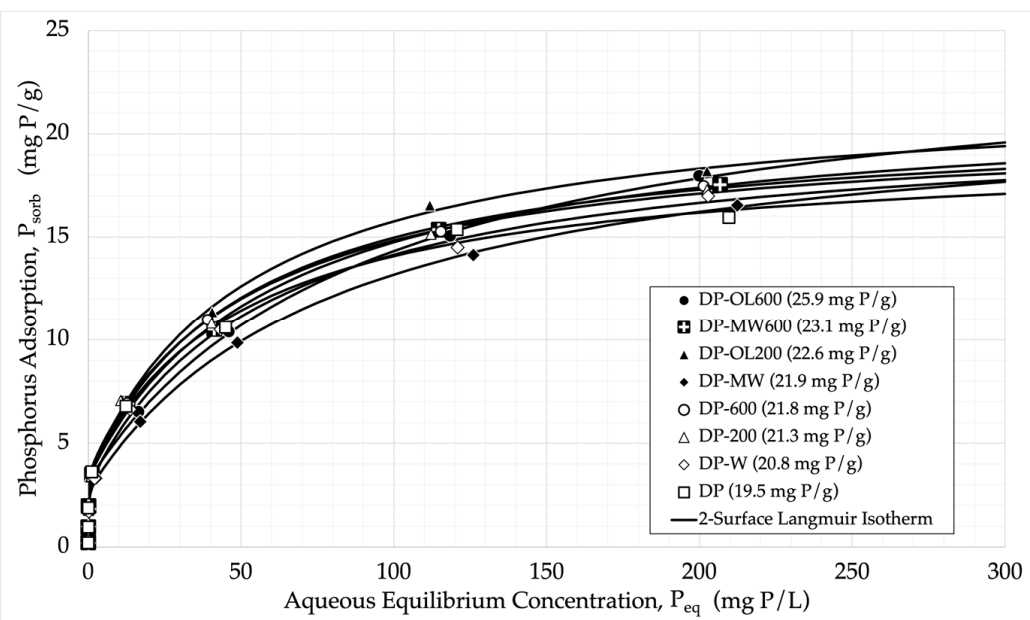

(b)

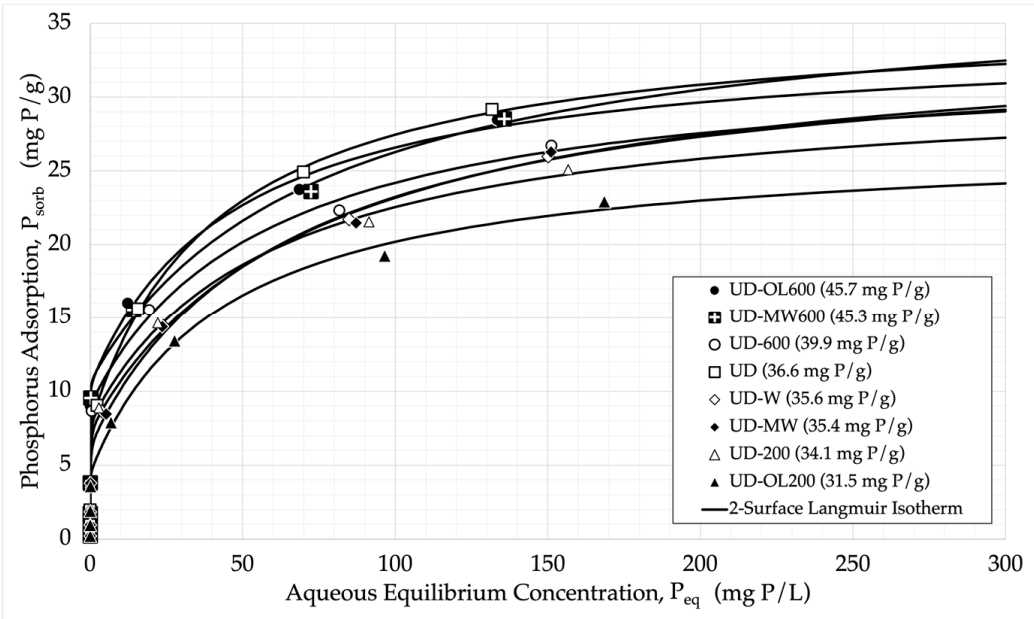

(c)

Figure 4. P sorption batch experimental data fitted with two-surface Langmuir isotherms for: (a) four air-dried DWTRs without treatment; (b) one air-dried and seven experimentally treated DWTRs from DP WTP; (c) one air-dried and seven experimentally treated DWTRs from UD WTP. The values in parentheses represent the total $\mathrm{P}$ sorption capacity $(b)$. 


\subsection{Nitrogen Desorption}

Overall, the DWTR from the UD WTP had more total N, as seen in the untreated (raw) form (Figure 5, left axis). Every treatment reduced total $\mathrm{N}$ contained within the dried sediment of both DWTRs. However, the amount of total $\mathrm{N}$ that was leached (as TKN) in the experiments varied, with some treatments being more successful in reducing $\mathrm{N}$ leachability (lighter bars in Figure 5, shown as a 1/10 scale, right axis). Laboratory analysis of $\mathrm{N}$ forms found that leachate had very low concentrations of nitrate and nitrite, while most of the TKN consisted of organic N (Supplementary Materials Table S3). Notably, the $200{ }^{\circ} \mathrm{C}$ heat treatments-both with and without oxygen limitation-were not effective at reducing $\mathrm{N}$ content or leachability. In fact, the mass of $\mathrm{N}$ that leached from DWTRs with oxygen-limited heat treatment at $200{ }^{\circ} \mathrm{C}$ increased, suggesting decomposition of organic $\mathrm{N}$ occurred. Washing reduced total $\mathrm{N}$ contents, with repeated washing (MW) reducing $\mathrm{N}$ further. The MW treatments showed very little $\mathrm{N}$ leaching, with less than $200 \mathrm{mg} \mathrm{N} / \mathrm{kg}$ DWTR, and resulted in nearly zero N leached for DP-MW. The ability of washing to reduce leachable $\mathrm{N}$ was likely limited by the volume of water used during washing. Because the amount of leachable $\mathrm{N}$ was higher in the UD DWTR relative to the DP DWTR, the volume of water used for washing may have been insufficient to remove the leachable $\mathrm{N}$ from this DWTR. Overall, the $600^{\circ} \mathrm{C}$ heat treatments reduced total $\mathrm{N}$ the most. When oxygen was limited during the $600{ }^{\circ} \mathrm{C}$ heat treatment, $\mathrm{N}$ leaching was eliminated entirely. Oxygen limitation likely sequestered $\mathrm{N}$ via formation of biochar, volatilizing $\mathrm{N}$ compounds, and forming stable aromatic compounds [51].

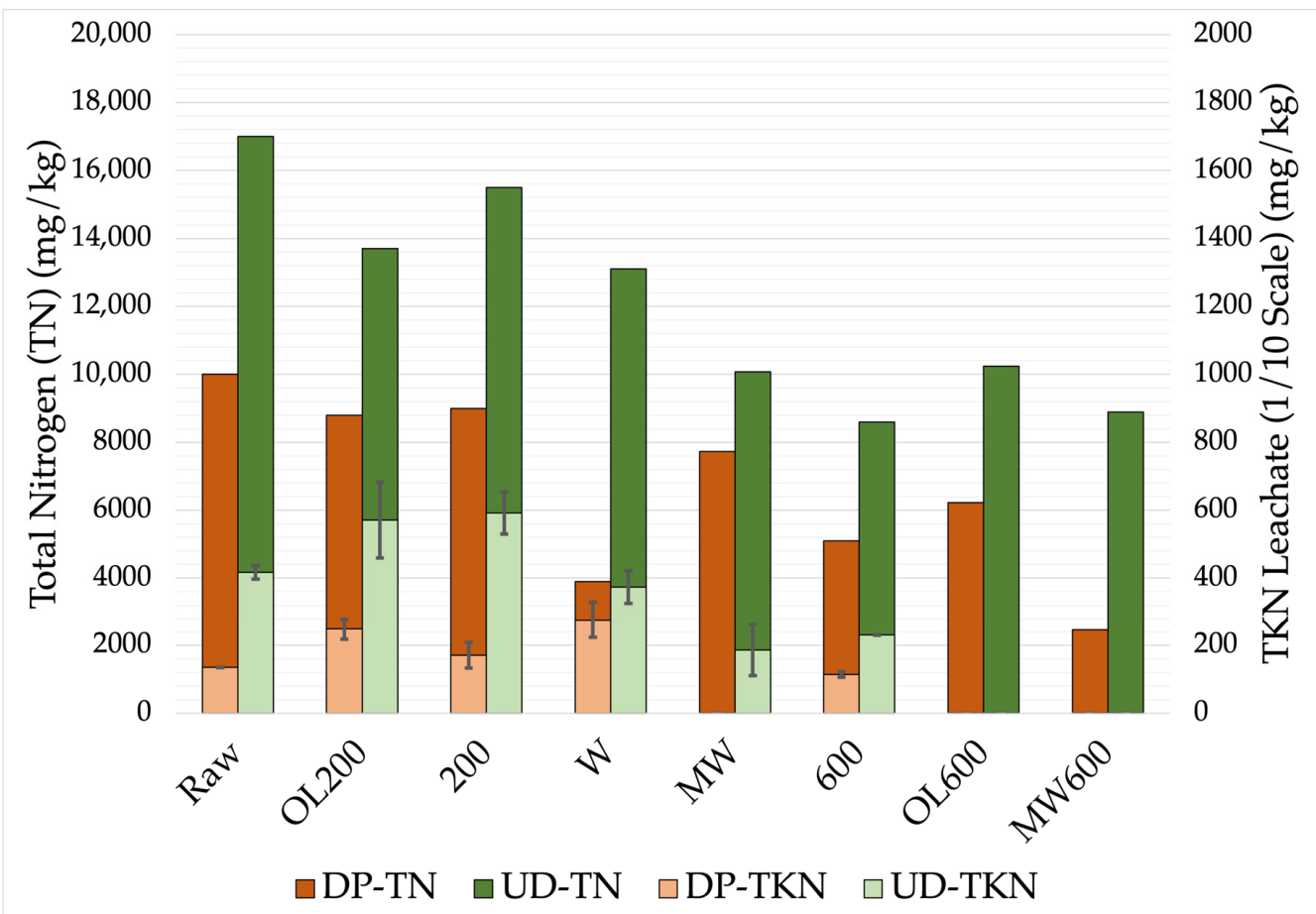

Figure 5. Total nitrogen (N) of DP DWTRs (brown) and UD DWTRs (green), as plotted on the left-hand y-axis. The average amount of $\mathrm{N}$, measured as TKN, that leached from the DWTRs during leaching experiments is shown in lighter colors on the right-hand y-axis (at 1/10 scale to TN). Bars represent range of TKN values $(n=3)$.

\subsection{Association of P Sorption Parameters with Physio-Chemical Characteristics}

Regression of each of the five P sorption outcomes derived from the two-surface Langmuir equation against the physio-chemical properties elucidated what mechanisms were driving $\mathrm{P}$ sorption. Overall, $\mathrm{Al}_{\mathrm{ox}}$ and $\mathrm{Fe}_{\mathrm{ox}}$ were significantly associated with $\mathrm{P}$ sorption. Total $\mathrm{P}$ sorption capacity was significantly associated with the sum of $\mathrm{Al}_{\mathrm{ox}}$ and 
$\mathrm{Fe}_{\text {ox }}$ (Table 5). Each of the P sorption components $\left(b_{1}\right.$ and $\left.b_{2}\right)$ were also associated with the sum of $\mathrm{Al}_{\mathrm{ox}}$ and $\mathrm{Fe}_{\mathrm{ox}}$. However, $b_{1}$ and $b_{2}$ were also associated with changes in the HK micropore volume. The high-affinity $\mathrm{P}$ sorption, $b_{1}$, was negatively correlated with micropore volume, while the low-affinity $\mathrm{P}$ sorption, $b_{2}$, was positively correlated with micropore volume. Additionally, $b_{2}$ was positively correlated with $\mathrm{P}_{\mathrm{ox}}$.

Table 5. Regression coefficients (95\% confidence intervals of coefficients) for five final linear regression models ( $\mathrm{n}=18$ ). The model for high-affinity capacity, $\mathrm{b}_{1}, \mathrm{~F}(2,15)=60.3(p<0.001)$ adjusted $\mathrm{R}^{2}=0.87$ had two significant factors $(\alpha=0.05)$. The model for low-affinity capacity, $\mathrm{b}_{2}, \mathrm{~F}(3,14)=25.6(p<0.001)$ adjusted $\mathrm{R}^{2}=0.81$ had three significant factors. The model for high-affinity binding energy constant, $\mathrm{K}_{1}, \mathrm{~F}(1,16)=35.0(p<0.001)$ adjusted $\mathrm{R}^{2}=0.67$ had one significant factor. No factors were significantly associated with the low-affinity binding energy constant, $\mathrm{K}_{2}$. The model for total $\mathrm{P}$ sorption capacity $\mathrm{F}(1,16)=253(p<0.001)$ adjusted $\mathrm{R}^{2}=0.94$ had one significant factor.

\begin{tabular}{|c|c|c|c|c|c|}
\hline Independent Variable & $b_{1}(\mathrm{~mol} / \mathrm{kg})$ & $b_{2}(\mathrm{~mol} / \mathrm{kg})$ & $\mathrm{K}_{1}(\mathrm{~L} / \mathrm{kg})$ & $\mathrm{K}_{2}(\mathrm{~L} / \mathrm{kg})$ & $\begin{array}{c}\text { P Sorption } \\
\text { Capacity (mol/kg) }\end{array}$ \\
\hline $\begin{array}{l}\text { Sum of } \mathrm{Al}_{\mathrm{ox}} \text { and } \mathrm{Fe}_{\mathrm{ox}} \\
(\mathrm{mol} / \mathrm{kg})\end{array}$ & $0.16(0.12-0.18)^{* * *}$ & $0.04(0.006-0.072) *$ & - & - & $0.21(0.18-0.24)^{* * *}$ \\
\hline $\begin{array}{l}\text { HK Micropore Volume } \\
\left(\mathrm{cm}^{3} / \mathrm{g}\right)\end{array}$ & $-3.75(-7.31--0.17) *$ & $5.07(1.82-8.32)^{* *}$ & - & - & - \\
\hline $\mathrm{P}_{\mathrm{ox}}(\mathrm{mol} / \mathrm{kg})$ & - & $7.69(3.03-12.36)^{* *}$ & - & - & - \\
\hline Aluminum (mg/g) & - & - & $0.91(0.57-1.24)^{* * *}$ & - & - \\
\hline
\end{tabular}

Despite considering several physio-chemical properties, the overall $\mathrm{P}$ sorption capacity (sum of $b_{1}$ and $b_{2}$ ) was well described $\left(\mathrm{R}^{2}=0.94\right.$ ) by a single parameter: the sum of $\mathrm{Al}_{\mathrm{ox}}$ and $\mathrm{Fe}_{\mathrm{ox}}$ (Figure 6). Collectively, these results suggest that the sorption kinetics and necessary concentration gradients are mediated by the pore structure and presence of occupied sorption sites.

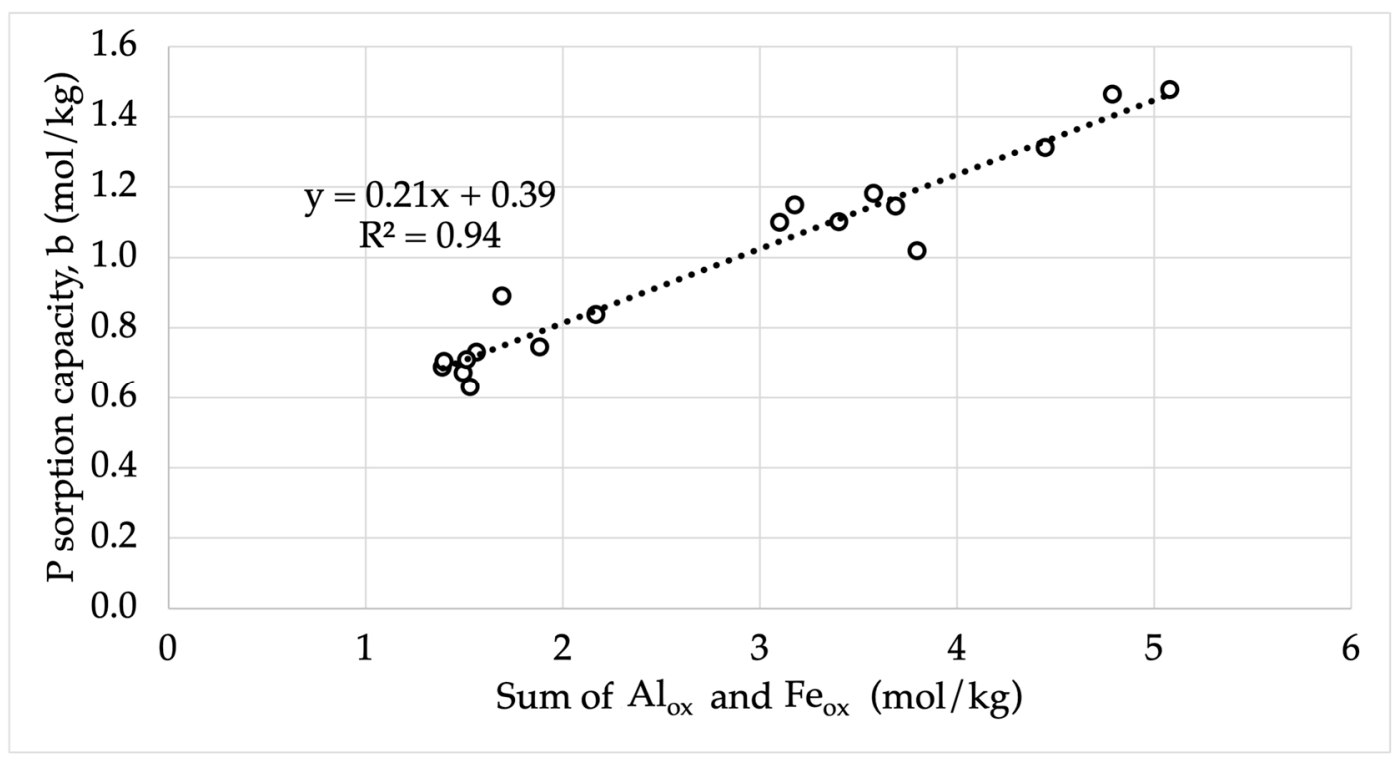

Figure 6. Maximum P sorption capacity (sum of $b_{1}$ and $b_{2}$ ) of DWTRs, as determined from two-surface Langmuir isotherm, plotted against sum of oxalate-extractable $\mathrm{Al}$ and $\mathrm{Fe}$, with linear regression $(\mathrm{n}=18)$.

\subsection{Effect of DWTR Treatment on Key Physio-Chemical Characteristics}

The aim of the research was to identify treatments of DWTR that resulted in higher P sorption capacity and lower desorption of N. From the results, it was determined that overall $\mathrm{P}$ sorption capacity was strongly associated with $\mathrm{Al}_{\mathrm{ox}}$ and $\mathrm{Fe}_{\mathrm{ox}}$ content and no other physio-chemical properties. Thus, in order to increase P sorption capacity, the aim 
should be to increase the $\mathrm{Al}_{\mathrm{ox}}$ content (ignoring $\mathrm{Fe}_{\mathrm{ox}}$, in this case, because the studied DWTRs were generated form the use of Al-based coagulants). However, the affinity of the $\mathrm{P}$ sorption reaction was modulated by micropore volume and $\mathrm{P}_{\mathrm{ox}}$. That is, micropore volume and $\mathrm{P}_{\mathrm{ox}}$ shifted $\mathrm{P}$ sorption to low-affinity reactions. However, it is unclear whether more high- or low-affinity sorption would be beneficial for DWTR applied to inactivate $P$ in lake sediment. Therefore, it is likely that treatment can focus primarily on increasing $\mathrm{Al}_{\mathrm{ox}}$ (and/or $\mathrm{Fe}_{\mathrm{ox}}$ ) and decreasing labile (i.e., releasable) $\mathrm{N}$ in DWTR.

Qualitatively comparing the results showed that oxygen-limited heat treatment at $600{ }^{\circ} \mathrm{C}$ was the optimal treatment method (Table 6). If the $600{ }^{\circ} \mathrm{C}$ heat treatment was not oxygen limited and included oxidation reactions (i.e., " $600^{\prime \prime}$ ), the results were favorable, but less so compared to when oxygen was limited. Lower-temperature treatments (i.e., at $200{ }^{\circ} \mathrm{C}$ ) did not improve the qualities of the DWTR and increased N lability. Finally, washing may be an option for reducing labile $\mathrm{N}$, as long as sufficient volumes of water are used, and multiple rounds of washing are conducted until $\mathrm{N}$ concentrations in leachate water are low. Multi-washing (in this study three times) reduced the lability of $\mathrm{N}$; however, it did not improve the $\mathrm{Al}_{\mathrm{ox}}$ content.

Table 6. Qualitative summary of treatment effects on key outcomes. Upward arrows indicate an increase in the outcome value whereas downward arrows indicate a decrease in the outcome. Green color indicates desirable improvement whereas red color indicates undesirable changes. The direction and color saturation indicate the strength of change. A level black arrow indicates negligible changes.

\begin{tabular}{|c|c|c|c|c|c|c|c|}
\hline Outcome & $\mathbf{W}$ & MW & 200 & OL200 & 600 & OL600 & MW600 \\
\hline $\mathrm{Al}_{\mathrm{ox}}$ & & & & & & & \\
\hline $\begin{array}{l}\text { TKN in } \\
\text { leachate }\end{array}$ & & & & & & & \\
\hline
\end{tabular}

\section{Discussion}

This study found that DWTRs had a very high P sorption capacity, and P sorption capacity was strongly correlated to the amount of oxalate-extractable (i.e., amorphous) $\mathrm{Al}$ and Fe in the DWTRs. Heat treatment at $600{ }^{\circ} \mathrm{C}$, especially under limited oxygen conditions, increased the concentration of amorphous $\mathrm{Al}$ and Fe and reduced the leachability of $\mathrm{N}$. Repeated washing of the DTWR was able to reduce N leachability if sufficient volume of water was used but did not confer any enhancements to P sorption capacity.

\subsection{Comparison of P Sorption Capacities}

Several studies have reported the P sorption capacities of DWTRs, as determined by equilibrating with orthophosphate solution under circumneutral $\mathrm{pH}$ conditions (Table 7). P sorption capacities previously reported for DWTRs ranged from 0.3 to $41.7 \mathrm{mg} \mathrm{P} / \mathrm{g}$. The P sorption capacities of the DWTRs in this study (19.5 to $45.7 \mathrm{mg} \mathrm{P} / \mathrm{g}$ ) were in the upper range of those values and in some cases exceeded the highest $\mathrm{P}$ sorption capacity previously reported for DWTRs.

The higher $\mathrm{P}$ sorption values reported in this study can be explained by four factors. First, this study used heat treatment to concentrate $\mathrm{Al}_{\text {ox }}$ and $\mathrm{Fe}_{\mathrm{ox}}$ and, thus, increase $\mathrm{P}$ sorption capacity. Previous P sorption studies used only air-dried DWTRs. The effect of heat treatment on adsorption in DWTRs has been previously investigated, but other sorbates were used, such as mercury [33]. Secondly, the DWTRs in this study were ground to a fine particle size $(<150 \mu \mathrm{m})$. Research has shown that grinding and sieving DWTRs to a smaller particle size increased the maximum P sorption capacity [20]. Correspondingly, the highest reported $\mathrm{P}$ sorption capacities were in studies that used particle sizes less than $600 \mu \mathrm{m}$ (Table 7). Thirdly, this study used a sufficiently long contact time (30 days) to reach sorption equilibrium. P sorption kinetics generally reach zero after 6 to 10 days, even 
when continuous agitation is used [20,52]. Fourthly, the use of alum (as opposed to PAC or other Al-based coagulants) in the WTP may be a factor that increased P sorption capacity. Alum may have required higher doses for coagulation or resulted in more amorphous structures in the DWTR. The raw water quality and amount and type of coagulant used are important determinants of the physio-chemical properties of DWTR and should be carefully considered before use in environmental remediation applications $[16,17]$.

Table 7. Orthophosphate sorption capacities of Al-based DWTRs at circumneutral pH determined from Langmuir isotherms.

\begin{tabular}{|c|c|c|c|c|c|c|}
\hline Country [Ref] & Coagulant & Particle Size & $\mathrm{v} / \mathrm{m}$ Ratio & Initial $\mathbf{P}$ & Contact Time & $\begin{array}{l}\text { Maximum Sorption } \\
\text { Capacity }^{1}\end{array}$ \\
\hline & & $(\mu \mathrm{m})$ & $(\mathrm{g} / \mathrm{mL})$ & $(\mathrm{mg} \mathrm{P} / \mathrm{L})$ & (days) & (mg P/g) \\
\hline Korea [53] & alum & $<2000$ & 30 & $100-4000$ & 0.6 & 25.0 \\
\hline USA [21] & alum & $100-300$ & 40 & 300 & 1 & 12.5 \\
\hline USA [54] & Al-based & $<2000$ & 25 & $0-100$ & 0.6 & $1.3(0.3-5.1)$ \\
\hline USA [20] & Al-based & $<150$ & 10 & $0-3500$ & 6 & $20.6(10.4-37.0)$ \\
\hline Ireland [55] & & $<63$ & & 5 & 2 & 2.5 \\
\hline Ireland [19] & alum & $<2360$ & 200-1000 & 4800 & 1 & 10.2 \\
\hline Ireland [56] & alum & $<63$ & 200-1000 & 100 & 2 & 13.7 (13.1-14.3) \\
\hline China [17] & $\mathrm{FeCl}_{3}+\mathrm{PAC}, \mathrm{PAC}$ & $<2000$ & 100 & 5-100 & 2 & $4.5(4.0-8.3)$ \\
\hline UK [52] & Al-based & $<2000$ & 25 & $0-1250$ & 10 & 28.8 \\
\hline Australia [57] & alum & $150-600$ & 200 & $0-600$ & 2 & $33.4(30.3-41.7)$ \\
\hline China [36] & alum & & & 100 & & $3.5(2.1-6.1)$ \\
\hline Thailand [this study] & alum, alum + PAC & $<150$ & 200 & $0-300$ & $30 *$ & $29.5(19.5-45.7)$ \\
\hline
\end{tabular}

1 = if several DWTRs were measured in study, median (range) reported. * = assays were not continuously agitated during the equilibrium period.

\subsection{Relating P Sorption to DWTR Properties}

There was a strong association between $\mathrm{P}$ sorption capacity and oxalate-extractable (i.e., amorphous) $\mathrm{Al}$ (and, to a lesser degree $\mathrm{Fe}$, as this study used DWTRs with Al-based coagulants), which is consistent with previous studies [20,58]. However, other studies have identified other parameters that were also associated with P sorption. For example, SSA has been shown to be associated with P sorption capacity [16]. While SSA was assessed in this study, it was not found to be associated with P sorption. Theoretically, SSA provides additional spaces for P sorption, but the chemical composition of the surface is important. The presence of carbon and organic material can confound the relationship between SSA and $\mathrm{P}$ sorption [22]. Overall, despite the inclusion of several physio-chemical properties into the initial regression model, only one variable-the sum of oxalate-extractable $\mathrm{Al}$ and $\mathrm{Fe}-$ was needed to describe $94 \%$ of the variation of total $\mathrm{P}$ sorption capacity in these DTWRs, creating a simpler model compared to some previously developed ones [16,17].

This study used a two-surface Langmuir isotherm to describe P sorption, which not only fit the data well and is most appropriate for describing P sorption to DWTRs [47,59], but was also able to separate the P sorption capacity into different components when combined with the regression results. Previous studies have described P sorption kinetics with $\mathrm{Al}$ hydroxides as having a rapid initial phase followed by a slower reaction rate where a true equilibrium may not be reached [60]. High quantities of $P$ can be sorbed within the first 15-30 min of kinetics studies [61]. However, additional $\mathrm{P}$ sorption occurs at a slower rate over a period of several days [49]. This initial rapid adsorption is likely a result of ligand exchange, whereas the slower phase is likely a result of surface precipitation and intraparticle diffusion into micropores [62]. Ligand exchange has been identified as a dominant $\mathrm{P}$ sorption mechanism in DWTRs [55]. However, precipitation and chemical reactions cannot be neglected $[63,64]$. Considering intraparticle diffusion, this mechanism may be driven by the concentration gradient of $\mathrm{P}$ at high concentrations, such as those used in the P sorption experiments of this study [65]. Thus, within the two-surface isotherm, the initial rapid high-affinity sorption phase was described by $b_{1}$, which was negatively correlated with micropore volume. The rate of this rapid phase was also related to Al content, indicating the role of $\mathrm{Al}$ in ligand exchange. The slower low-affinity phase, 
which required higher equilibrium concentrations in the sorption batch experiments, was described by $b_{2}$, which positively correlated with the micropore volume. Finally, oxalateextractable $\mathrm{P}, \mathrm{P}_{\mathrm{ox}}$, was positively associated with $b_{2}$. $\mathrm{P}_{\mathrm{ox}}$ has been used to represent the amount of $\mathrm{P}$ sorption sites that are occupied, and higher levels of $\mathrm{P}_{\mathrm{ox}}$ could indicate more sorption sites saturated with P [58]. The organic content in DWTRs has also been shown to slow $\mathrm{P}$ diffusion into micropores [22], which would shift $\mathrm{P}$ sorption towards the low-affinity capacity, $b_{2}$.

\subsection{P Binding Efficiency of DWTR}

The slope of the relationship between molar P sorbed and sum of molar amorphous $\mathrm{Al}$ and $\mathrm{Fe}(0.21)$ was 1.5 times higher in this study, which used a 30-day equilibrium period, when compared to a slope derived from a 6-day equilibrium (0.14) [20]. Therefore, it is likely that greater equilibrium time may explain the steeper slope (i.e., more efficient $\mathrm{P}$ binding) found in this study. Furthermore, this slope (using molar units) represents an approximate $5: 1$ ratio of $\left(\mathrm{Al}_{\mathrm{ox}}+\mathrm{Fe}_{\mathrm{ox}}\right): \mathrm{P}$ sorbed, which is a relatively efficient binding ratio. In vitro studies of binding between freshly formed Al hydroxides and lake P sediment have shown high (i.e., inefficient) binding ratios of 20-100:1 [66-68]. However, the binding efficiency shown in this study is similar to in situ binding efficiencies between lake sediment $\mathrm{P}$ and aged $\mathrm{Al}$ hydroxides over a period of years, which were generally less than 11:1 [69-71]. Thus, this 5:1 binding efficiency ratio may represent an appropriate method for determining the dosage of DWTR for P inactivation in lake sediment. In fact, dosage of DWTR for sediment $\mathrm{P}$ inactivation has been proposed as a function of the mobile $\mathrm{P}$ in the sediment and sum of $\mathrm{Al}_{\mathrm{ox}}$ and $\mathrm{Fe}_{\mathrm{ox}}$ content in the DWTR [72]. That study, however, proposed an 83:1 ratio of $\left(\mathrm{Al}_{\mathrm{ox}}+\mathrm{Fe}_{\mathrm{ox}}\right): \mathrm{P}$ sorbed, determined from in vitro experiments that considered changes in inorganic mobile P. A review of Al dosing methods (not necessarily DWTR), however, has shown that this approach can underestimate the P binding efficiency and recommended considering a larger pool of $\mathrm{P}$ that includes labile organic $\mathrm{P}$ but also a lower ratio of 11:1 [67].

\subsection{Considerations for Treatment of DWTR}

This study showed that oxygen-limited treatment at $600{ }^{\circ} \mathrm{C}$ produced the desired results of high $\mathrm{P}$ sorption capacity and very low $\mathrm{N}$ desorption. However, treatment effects produced some inconsistent results among the two DWTRs investigated. The inherent properties of DWTR can result in variable effects of treatments on properties [32]. For example, the multi-washing treatment was able to eliminate leaching of TKN from the DP DWTR, which was consistent with previous research showing desorption of $\mathrm{N}$ was effectively eliminated after three rounds of washing at a 1:20 m/v ratio [29]. However, despite using that same washing regimen, TKN was still released from the UD DWTR. This may be due to the higher amount of $\mathrm{N}$ present in the raw UD DWTR. Washing (i.e., dissolving in deionized water) relies on mobilizing fine particles and can remove finite amounts of materials, limited by the saturation limits and volume of water used. Therefore, the mass-to-volume ratio and number of washing rounds probably needs to be varied for each DWTR in order to achieve acceptably low levels of $\mathrm{N}$ release to the water column.

The temperature of heat treatment was important to affect the DWTR properties. Oxygen-limited heat treatment at relatively low temperatures of $200-300{ }^{\circ} \mathrm{C}$ has been shown to induce decomposition of organic matter, transforming humin organic matter to fulvic and humic acids [33]. This likely explains the limited reduction, or even increase, in $\mathrm{N}$ lability found in this study from $200{ }^{\circ} \mathrm{C}$ treatments. Furthermore, the presence of oxygen during heat treatment was an important factor in this study, resulting in DWTRs that differed substantially, despite being treated at equivalent temperatures for equivalent times. The presence of oxygen during heat treatment creates oxidation reactions. However, under oxygen-limited conditions at higher temperatures of 500-600 ${ }^{\circ} \mathrm{C}$, carbonization and pyrolysis occurs, removing most organic matter and leaving only the more stable humin form of organic matter [31]. 
The $\mathrm{Al}_{\mathrm{ox}}$ content increased from oxygen-limited heat treatment at high temperatures (i.e., $600^{\circ} \mathrm{C}$ ). While not investigated in this study, previous work has showed even greater increases in $\mathrm{Al}_{\mathrm{ox}}$ can be achieved from $4 \mathrm{~h}$ of oxygen-limited treatment at temperatures of 300-400 ${ }^{\circ} \mathrm{C}$ [33]. Notably, because the DWTRs used in this study were taken directly from the sedimentation tanks, they contained a relatively high amount of organic matter, which may have inhibited aging of amorphous Al that occurs during heat treatment [73], allowing the $\mathrm{Al}_{\mathrm{ox}}$ to remain high despite the higher $600{ }^{\circ} \mathrm{C}$ temperature used. The increase in the concentration of $\mathrm{Al}_{\mathrm{Ox}}$ and resulting increase in $\mathrm{P}$ sorption capacity per mass seen following $600{ }^{\circ} \mathrm{C}$ pyrolysis was likely the result of a reduction in the total non- $\mathrm{Al}$ mass but also structural chemical changes that occurred [74]. However, it was not possible to differentiate these two processes in this study.

Oxygen-limited heat treatment at $600{ }^{\circ} \mathrm{C}$ substantially reduced the amount of $\mathrm{N}$ and lability of remaining $\mathrm{N}$ in DWTRs as well. The release of $\mathrm{N}$ and organic matter is a major concern in the use of DWTRs for lake remediation [29]. DWTR treated at high temperatures (e.g., $500^{\circ} \mathrm{C}$ ) can result in a product that can sorb $\mathrm{P}$ and facilitate the growth of nitrifying bacterial colonies that result in $\mathrm{N}$ reduction, introducing an additional $\mathrm{N}$ removal pathway [75]. Irrespective of this finding, reducing the potential contribution of organic matter and N via addition of DWTR to lakes is likely necessary, as both can potentially contribute to degradation of water quality via reduced dissolved oxygen and contributions to algal growth in N-limited systems [76].

This study did not address the lability of the metals contained in the DWTRs. Previous research has shown that the most abundant metals $\mathrm{Al}, \mathrm{Fe}$, and $\mathrm{Mn}$ can be released from DWTR to the water column under anaerobic (reductive) conditions [77]. Chronic and/or high-concentration exposure to fresh sedimentation sludge has been shown to have harmful effects on the Daphnia genus, which is used as an indicator organism [78,79]. However, ecological and human health risk assessments have shown limited risks $[80,81]$, especially when de-watering or treatment was completed before use of DWTR in environmental application [82]. Again, oxygen-limited heat treatment may be the most reliably safe choice for treatment. Pyrolysis has been shown to effectively fix heavy metals and reduce leaching compared to untreated sediments [74], various sludges [83], and DWTRs [33]. Nevertheless, while outside the scope of this research, the potential lability of metals needs to be considered before widescale application.

A final consideration is the economic and technological feasibility of the different treatments applied to the DWTR. The need to treat DWTR with slow-rate pyrolysis at $600{ }^{\circ} \mathrm{C}$ introduces a substantial energy requirement, and the need to limit oxygen presents an engineering challenge when scaled to produce enough DWTR for lake restoration. However, commercial modular biomass-to-biochar pyrolysis systems exist, able to produce 200 to 500 tons of biochar per year [84]. However, if these costs render DWTR more expensive than readily available and cheap alum, then the feasibility of DWTR as a solidphase P sorbent is limited. On the other hand, DWTR has ballast mass, a quality not found in floc from Al-based coagulants. Therefore, DWTR may be appropriate for use in combination with a low-dose coagulant, an approach known as "flock and lock" $[85,86]$.

\section{Conclusions}

Drinking water treatment residuals have an inherently high phosphorus sorption capacity that is strongly related to the oxalate-extractable aluminum and iron present in the sludge. Therefore, this waste product can be recycled and used for removal of phosphorus from the environment. However, in a raw oven-dried form, substantial quantities of nitrogen were released from the residuals, which is undesirable for already eutrophic waters. Oxygen-limited heat treatment at $600{ }^{\circ} \mathrm{C}$ for two hours was able to reliably reduce the lability of nitrogen, though. Washing with water may also be able to remove labile nitrogen; however, sufficient washing volume is necessary in proportion to the amount of nitrogen present in the raw residuals. Oxygen-limited heat treatment at $600{ }^{\circ} \mathrm{C}$ offered additional benefits, including removing mass of volatile solids, which concentrated oxalate- 
extractable aluminum and improved phosphorus sorption capacity. Heat treatment at $200{ }^{\circ} \mathrm{C}$ and treatment in the presence of oxygen were neither able to reduce nitrogen lability nor enhance phosphorus sorption. Overall, reusing residual sludge from drinking water sedimentation for environmental remediation is an attractive option to reduce waste and increase the sustainability of urban environments. However, the technological scalability and economic feasibility need to be investigated.

Supplementary Materials: The following are available online at https:/ /www.mdpi.com/article/10 $.3390 / w 13182465 / s 1$, Table S1: Chemical concentrations of raw and treated DWTRs per unit mass of dry sludge, Table S2: Concentration of $\mathrm{Al}, \mathrm{Fe}$, and forms of $\mathrm{N}$ in wastewater generated during single washing $(\mathrm{W})$. In total, $100 \mathrm{~g}$ of dry DWTR was dissolved in $1 \mathrm{~L}$ of water $(1: 10 \mathrm{~m} / \mathrm{v}$ ratio), Table S3: Average mass of nitrogen $(\mathrm{N})$ leached into deionized water $(\mathrm{n}=3)$ during leaching tests per unit of dry DWTR mass, as categorized by form of $\mathrm{N}$.

Author Contributions: Conceptualization, A.C.K., B.J.H. and A.T.K.; methodology, A.C.K., B.J.H. and A.T.K.; formal analysis, A.C.K.; investigation, A.C.K.; resources, S.P., R.J. and A.T.K.; data curation, A.C.K. and A.T.K.; writing-original draft preparation, A.C.K., B.J.H. and A.T.K.; writingreview and editing, A.C.K. and B.J.H.; visualization, A.C.K. and A.T.K.; supervision, R.J. and A.T.K.; project administration, A.T.K.; funding acquisition, A.C.K., S.P. and A.T.K. All authors have read and agreed to the published version of the manuscript.

Funding: This research was funded by Research and Graduate Studies, Khon Kaen University, grant number RP64005. The APC was also funded by Research and Graduate Studies, Khon Kaen University, grant number RP64005.

Institutional Review Board Statement: Not applicable.

Informed Consent Statement: Not applicable.

Data Availability Statement: Raw data can be provided upon request.

Acknowledgments: We would like to express our gratitude to Wasana Wattanakul at the PWA Region Training Center 2 for providing the sediment sludge and access to sampling.

Conflicts of Interest: The authors declare no conflict of interest.

\section{References}

1. Paerl, H.W.; Barnard, M.A. Mitigating the Global Expansion of Harmful Cyanobacterial Blooms: Moving Targets in a Humanand Climatically-Altered World. Harmful Algae 2020, 96, 101845. [CrossRef]

2. Carpenter, S.R. Phosphorus Control Is Critical to Mitigating Eutrophication. Proc. Natl. Acad. Sci. USA 2008, 105, 11039-11040. [CrossRef] [PubMed]

3. Paerl, H.W.; Havens, K.E.; Xu, H.; Zhu, G.; McCarthy, M.J.; Newell, S.E.; Scott, J.T.; Hall, N.S.; Otten, T.G.; Qin, B. Mitigating Eutrophication and Toxic Cyanobacterial Blooms in Large Lakes: The Evolution of a Dual Nutrient (N and P) Reduction Paradigm. Hydrobiologia 2020, 847, 4359-4375. [CrossRef]

4. Douglas, G.B.; Hamilton, D.P.; Robb, M.S.; Pan, G.; Spears, B.M.; Lurling, M. Guiding Principles for the Development and Application of Solid-Phase Phosphorus Adsorbents for Freshwater Ecosystems. Aquat. Ecol. 2016, 50, 385-405. [CrossRef]

5. Jančula, D.; Maršálek, B. Critical Review of Actually Available Chemical Compounds for Prevention and Management of Cyanobacterial Blooms. Chemosphere 2011, 85, 1415-1422. [CrossRef]

6. Wang, C.; Jiang, H.-L. Chemicals Used for in Situ Immobilization to Reduce the Internal Phosphorus Loading from Lake Sediments for Eutrophication Control. Crit. Rev. Environ. Sci. Technol. 2016, 46, 947-997. [CrossRef]

7. Huser, B.J.; Egemose, S.; Harper, H.; Hupfer, M.; Jensen, H.; Pilgrim, K.M.; Reitzel, K.; Rydin, E.; Futter, M. Longevity and Effectiveness of Aluminum Addition to Reduce Sediment Phosphorus Release and Restore Lake Water Quality. Water Res. 2016, 97, 122-132. [CrossRef]

8. Huser, B.J.; Futter, M.; Lee, J.T.; Perniel, M. In-Lake Measures for Phosphorus Control: The Most Feasible and Cost-Effective Solution for Long-Term Management of Water Quality in Urban Lakes. Water Res. 2016, 97, 142-152. [CrossRef]

9. Gensemer, R.W.; Gondek, J.C.; Rodriquez, P.H.; Arbildua, J.J.; Stubblefield, W.A.; Cardwell, A.S.; Santore, R.C.; Ryan, A.C.; Adams, W.J.; Nordheim, E. Evaluating the Effects of PH, Hardness, and Dissolved Organic Carbon on the Toxicity of Aluminum to Freshwater Aquatic Organisms under Circumneutral Conditions. Environ. Toxicol. Chem. 2018, 37, 49-60. [CrossRef]

10. De Vicente, I.; Jensen, H.S.S.; Andersen, F.Ø.O. Factors Affecting Phosphate Adsorption to Aluminum in Lake Water: Implications for Lake Restoration. Sci. Total Environ. 2008, 389, 29-36. [CrossRef] 
11. De Vicente, I.; Huang, P.; Andersen, F.Ø.; Jensen, H.S. Phosphate Adsorption by Fresh and Aged Aluminum Hydroxide. Consequences for Lake Restoration. Environ. Sci. Technol. 2008, 42, 6650-6655. [CrossRef]

12. Wang, Q.; Liao, Z.; Yao, D.; Yang, Z.; Wu, Y.; Tang, C. Phosphorus Immobilization in Water and Sediment Using Iron-Based Materials: A Review. Sci. Total Environ. 2021, 767, 144246. [CrossRef] [PubMed]

13. Jilbert, T.; Couture, R.-M.; Huser, B.J.; Salonen, K. Preface: Restoration of Eutrophic Lakes: Current Practices and Future Challenges. Hydrobiologia 2020, 847, 4343-4357. [CrossRef]

14. Kelly Vargas, K.G.; Qi, Z. P Immobilizing Materials for Lake Internal Loading Control: A Review towards Future Developments. Crit. Rev. Environ. Sci. Technol. 2019, 49, 518-552. [CrossRef]

15. Zhao, Y.; Nzihou, A.; Ren, B.; Lyczko, N.; Shen, C.; Kang, C.; Ji, B. Waterworks Sludge: An Underrated Material for Beneficial Reuse in Water and Environmental Engineering. Waste Biomass Valorization 2020, 12, 4239-4251. [CrossRef]

16. Al-Tahmazi, T.; Babatunde, A.O. Mechanistic Study of P Retention by Dewatered Waterworks Sludges. Environ. Technol. Innov. 2016, 6, 38-48. [CrossRef]

17. Bai, L.; Wang, C.; He, L.; Pei, Y. Influence of the Inherent Properties of Drinking Water Treatment Residuals on Their Phosphorus Adsorption Capacities. J. Environ. Sci. 2014, 26, 2397-2405. [CrossRef]

18. Turner, T.; Wheeler, R.; Stone, A.; Oliver, I. Potential Alternative Reuse Pathways for Water Treatment Residuals: Remaining Barriers and Questions-A Review. Water Air Soil Pollut. 2019, 230. [CrossRef]

19. Razali, M.; Zhao, Y.Q.; Bruen, M. Effectiveness of a Drinking-Water Treatment Sludge in Removing Different Phosphorus Species from Aqueous Solution. Sep. Purif. Technol. 2007, 55, 300-306. [CrossRef]

20. Dayton, E.; Basta, N.T. A Method for Determining the Phosphorus Sorption Capacity and Amorphous Aluminum of AluminumBased Drinking Water Treatment Residuals. J. Environ. Qual. 2005, 34, 1112-1118. [CrossRef]

21. Ippolito, J.A.; Barbarick, K.A.; Heil, D.M.; Chandler, J.P.; Redente, E.F. Phosphorus Retention Mechanisms of a Water Treatment Residual. J. Environ. Qual. 2003, 32, 1857-1864. [CrossRef]

22. Makris, K.C.; Harris, W.G.; O'Connor, G.A.; Obreza, T.A.; Elliott, H.A. Physicochemical Properties Related to Long-Term Phosphorus Retention by Drinking-Water Treatment Residuals. Environ. Sci. Technol. 2005, 39, 4280-4289. [CrossRef] [PubMed]

23. Soleimanifar, H.; Deng, Y.; Wu, L.; Sarkar, D. Water Treatment Residual (WTR)-Coated Wood Mulch for Alleviation of Toxic Metals and Phosphorus from Polluted Urban Stormwater Runoff. Chemosphere 2016, 154, 289-292. [CrossRef] [PubMed]

24. Babatunde, A.O.; Zhao, Y.Q.; Zhao, X.H. Alum Sludge-Based Constructed Wetland System for Enhanced Removal of P and OM from Wastewater: Concept, Design and Performance Analysis. Bioresour. Technol. 2010, 101, 6576-6579. [CrossRef] [PubMed]

25. Xu, D.; Lee, L.Y.; Lim, F.Y.; Lyu, Z.; Zhu, H.; Ong, S.L.; Hu, J. Water Treatment Residual: A Critical Review of Its Applications on Pollutant Removal from Stormwater Runoff and Future Perspectives. J. Environ. Manag. 2020, 259, 109649. [CrossRef]

26. Ichihara, M.; Nishio, T. Suppression of Phosphorus Release from Sediments Using Water Clarifier Sludge as Capping Material. Environ. Technol. 2013, 34, 2291-2299. [CrossRef] [PubMed]

27. Wang, C.; Qi, Y.; Pei, Y. Laboratory Investigation of Phosphorus Immobilization in Lake Sediments Using Water Treatment Residuals. Chem. Eng. J. 2012, 209, 379-385. [CrossRef]

28. Wang, C.; Wu, Y.; Bai, L.; Wang, C.; Jiang, H.; Wei, Z.; Wei, X.; Yuan, Z.; Liu, X. Intermittent Aeration Incubation of Drinking Water Treatment Residuals for Recycling in Aquatic Environment Remediation. J. Clean. Prod. 2018, 183, 220-230. [CrossRef]

29. Wang, C.; Liu, X.; Wang, M.; Shen, X.; Bai, L.; Yuan, A.; Xu, H.; Jiang, H. Desorption of Nitrogen from Drinking Water Treatment Residue: Implications for Environmental Recycling. J. Clean. Prod. 2019, 226, 96-105. [CrossRef]

30. Bai, L.; Wang, C.; Huang, C.; He, L.; Pei, Y. Reuse of Drinking Water Treatment Residuals as a Substrate in Constructed Wetlands for Sewage Tertiary Treatment. Ecol. Eng. 2014, 70, 295-303. [CrossRef]

31. Wang, C.; Wu, Y.; Bai, L.; Zhao, Y.; Yan, Z.; Jiang, H.; Liu, X. Recycling of Drinking Water Treatment Residue as an Additional Medium in Columns for Effective P Removal from Eutrophic Surface Water. J. Environ. Manag. 2018, 217, 363-372. [CrossRef] [PubMed]

32. Wang, C.; Yuan, N.; Bai, L.; Jiang, H.-L.; Pei, Y.; Yan, Z. Key Factors Related to Drinking Water Treatment Residue Selection for Adsorptive Properties Tuning via Oxygen-Limited Heat Treatment. Chem. Eng. J. 2016, 306, 897-907. [CrossRef]

33. Wang, C.; Jiang, H.-L.; Yuan, N.; Pei, Y.; Yan, Z. Tuning the Adsorptive Properties of Drinking Water Treatment Residue via Oxygen-Limited Heat Treatment for Environmental Recycle. Chem. Eng. J. 2016, 284, 571-581. [CrossRef]

34. Wang, C.; Yuan, N.; Pei, Y.; Jiang, H.-L. Aging of Aluminum/Iron-Based Drinking Water Treatment Residuals in Lake Water and Their Association with Phosphorus Immobilization Capability. J. Environ. Manag. 2015, 159, 178-185. [CrossRef]

35. Ren, B.; Zhao, Y.; Ji, B.; Wei, T.; Shen, C. Granulation of Drinking Water Treatment Residues: Recent Advances and Prospects. Water 2020, 12, 1400. [CrossRef]

36. Hou, Q.; Meng, P.; Pei, H.; Hu, W.; Chen, Y. Phosphorus Adsorption Characteristics of Alum Sludge: Adsorption Capacity and the Forms of Phosphorus Retained in Alum Sludge. Mater. Lett. 2018, 229, 31-35. [CrossRef]

37. Shen, C.; Zhao, Y.; Li, W.; Yang, Y.; Liu, R.; Morgen, D. Global Profile of Heavy Metals and Semimetals Adsorption Using Drinking Water Treatment Residual. Chem. Eng. J. 2019, 372, 1019-1027. [CrossRef]

38. Xu, H.; Pei, H.; Jin, Y.; Ma, C.; Wang, Y.; Sun, J.; Li, H. High-Throughput Sequencing Reveals Microbial Communities in Drinking Water Treatment Sludge from Six Geographically Distributed Plants, Including Potentially Toxic Cyanobacteria and Pathogens Sci. Total Environ. 2018, 634, 769-779. [CrossRef]

39. Bremner, J.M. Nitrogen-Total. Methods Soil Anal. 1996, 5, 1085-1121. 
40. Kasenow, M. Determination of Hydraulic Conductivity from Grain Size Analysis; Water Resources Publications: Denver, CO, USA, 2010.

41. Bertsch, P.M.; Bloom, P.R. Aluminum. In Methods of Soil Analysis Part 3-Chemical Methods; SSSA Book Series; Soil Science Society of America: Madison, WI, USA, 1996; pp. 517-550.

42. Jan, J.; Borovec, J.; Kopacek, J.; Hejzlar, J. Assessment of Phosphorus Associated with Fe and Al (Hydr)Oxides in Sediments and Soils. J. Soils Sediments 2015, 15, 1620-1629. [CrossRef]

43. Cucarella, V.; Renman, G. Phosphorus Sorption Capacity of Filter Materials Used for On-Site Wastewater Treatment Determined in Batch Experiments-A Comparative Study. J. Environ. Qual. 2009, 38, 381-392. [CrossRef]

44. Sui, Y.; Thompson, M.L. Phosphorus Sorption, Desorption, and Buffering Capacity in a Biosolids-Amended Mollisol. Soil Sci. Soc. Am. J. 2000, 64, 164-169. [CrossRef]

45. Sposito, G. On the Use of the Langmuir Equation in the Interpretation of "Adsorption" Phenomena: II. The "Two-Surface" Langmuir Equation. Soil Sci. Soc. Am. J. 1982, 46, 1147-1152. [CrossRef]

46. Zhou, A.; Tang, H.; Wang, D. Phosphorus Adsorption on Natural Sediments: Modeling and Effects of PH and Sediment Composition. Water Res. 2005, 39, 1245-1254. [CrossRef]

47. Bolster, C.H.; Hornberger, G.M. On the Use of Linearized Langmuir Equations. Soil Sci. Soc. Am. J. 2007, 71, 1796-1806. [CrossRef]

48. Nash, J.E.; Sutcliffe, J.V. River Flow Forecasting through Conceptual Models Part I-A Discussion of Principles. J. Hydrol. 1970, 10, 282-290. [CrossRef]

49. Makris, K.C.; Harris, W.G.; O'Connor, G.A.; El-Shall, H. Long-Term Phosphorus Effects on Evolving Physicochemical Properties of Iron and Aluminum Hydroxides. J. Colloid Interface Sci. 2005, 287, 552-560. [CrossRef]

50. Thommes, M.; Kaneko, K.; Neimark, A.V.; Olivier, J.P.; Rodriguez-Reinoso, F.; Rouquerol, J.; Sing, K.S.W. Physisorption of Gases, with Special Reference to the Evaluation of Surface Area and Pore Size Distribution (IUPAC Technical Report). Pure Appl. Chem. 2015, 87, 1051-1069. [CrossRef]

51. De Souza Souza, C.; Bomfim, M.R.; de Almeida, M.D.C.; de Souza Alves, L.; de Santana, W.N.; da Silva Amorim, I.C.; Santos, J.A.G. Induced Changes of Pyrolysis Temperature on the Physicochemical Traits of Sewage Sludge and on the Potential Ecological Risks. Sci. Rep. 2021, 11, 974. [CrossRef]

52. Habibiandehkordi, R.; Quinton, J.N.; Surridge, B.W.J. Effect of Equilibration Time on Estimates of the Maximum Phosphorus Sorption Capacity of Industrial By-Products Using the Langmuir Model. J. Soils Sediments 2014, 14, 1818-1828. [CrossRef]

53. Gon Kim, J.; Hyun Kim, J.; Moon, H.-S.; Chon, C.-M.; Sung Ahn, J. Removal Capacity of Water Plant Alum Sludge for Phosphorus in Aqueous Solutions. Chem. Speciat. Bioavailab. 2002, 14, 67-73. [CrossRef]

54. Dayton, E.; Basta, N.T.; Jakober, C.A.; Hattey, J.A. Using Treatment Residuals to Reduce Phosphorus in Agricultural Runoff. J. Am. Water Works Assoc. 2003, 95, 151-158. [CrossRef]

55. Yang, Y.; Zhao, Y.Q.; Babatunde, A.O.; Wang, L.; Ren, Y.X.; Han, Y. Characteristics and Mechanisms of Phosphate Adsorption on Dewatered Alum Sludge. Sep. Purif. Technol. 2006, 51, 193-200. [CrossRef]

56. Zhao, Y.Q.; Yang, Y. Extending the Use of Dewatered Alum Sludge as a P-Trapping Material in Effluent Purification: Study on Two Separate Water Treatment Sludges. J. Environ. Sci. Health Part A 2010, 45, 1234-1239. [CrossRef] [PubMed]

57. Bal Krishna, K.C.; Aryal, A.; Jansen, T. Comparative Study of Ground Water Treatment Plants Sludges to Remove Phosphorous from Wastewater. J. Environ. Manag. 2016, 180, 17-23. [CrossRef] [PubMed]

58. Shen, X.; Yuan, N.; Wang, C. The Bioturbation Effect of the Snail Bellamya Aeruginosa on Phosphorus Immobilisation by Drinking Water Treatment Residue in Sediment: A Long-Term Continuous Flow Test. J. Environ. Manag. 2020, 266, 110579. [CrossRef] [PubMed]

59. Gao, S.; Wang, C.; Pei, Y. Comparison of Different Phosphate Species Adsorption by Ferric and Alum Water Treatment Residuals. J. Environ. Sci. 2013, 25, 986-992. [CrossRef]

60. Bolan, N.S.; Barrow, N.J.; Posner, A.M. Describing the Effect of Time on Sorption of Phosphate by Iron and Aluminium Hydroxides. J. Soil Sci. 1985, 36, 187-197. [CrossRef]

61. Wagner, D.J.; Elliott, H.A.; Brandt, R.C.; Jaiswal, D. Managing Biosolids Runoff Phosphorus Using Buffer Strips Enhanced with Drinking Water Treatment Residuals. J. Environ. Qual. 2008, 37, 1567-1574. [CrossRef]

62. Makris, K.C.; Harris, W.G.; O'Conno, G.A.; Obreza, T.A. Phosphorus Immobilization in Micropores of Drinking-Water Treatment Residuals: Implications for Long-Term Stability. Environ. Sci. Technol. 2004, 38, 6590-6596. [CrossRef]

63. Muisa, N.; Nhapi, I.; Ruziwa, W.; Manyuchi, M.M. Utilization of Alum Sludge as Adsorbent for Phosphorus Removal in Municipal Wastewater: A Review. J. Water Process Eng. 2020, 35, 101187. [CrossRef]

64. Zhao, W.; Xie, H.; Li, J.; Zhang, L.; Zhao, Y. Application of Alum Sludge in Wastewater Treatment Processes: "Science" of Reuse and Reclamation Pathways. Processes 2021, 9, 612. [CrossRef]

65. Babatunde, A.O.; Zhao, Y.Q. Equilibrium and Kinetic Analysis of Phosphorus Adsorption from Aqueous Solution Using Waste Alum Sludge. J. Hazard. Mater. 2010, 184, 746-752. [CrossRef]

66. James, W.F. Variations in the Aluminum:Phosphorus Binding Ratio and Alum Dosage Considerations for Half Moon Lake, Wisconsin. Lake Reserv. Manag. 2011, 27, 128-137. [CrossRef]

67. Kuster, A.C.; Kuster, A.T.; Huser, B.J. A Comparison of Aluminum Dosing Methods for Reducing Sediment Phosphorus Release in Lakes. J. Environ. Manag. 2020, 261, 110195. [CrossRef] [PubMed] 
68. Huser, B.J.; Pilgrim, K.M. A Simple Model for Predicting Aluminum Bound Phosphorus Formation and Internal Loading Reduction in Lakes after Aluminum Addition to Lake Sediment. Water Res. 2014, 53, 378-385. [CrossRef]

69. Huser, B.J. Variability in Phosphorus Binding by Aluminum in Alum Treated Lakes Explained by Lake Morphology and Aluminum Dose. Water Res. 2012, 46, 4697-4704. [CrossRef]

70. Huser, B.J. Aluminum Application to Restore Water Quality in Eutrophic Lakes: Maximizing Binding Efficiency between Aluminum and Phosphorus. Lake Reserv. Manag. 2017, 33, 143-151. [CrossRef]

71. Schütz, J.; Rydin, E.; Huser, B.J. A Newly Developed Injection Method for Aluminum Treatment in Eutrophic Lakes: Effects on Water Quality and Phosphorus Binding Efficiency. Lake Reserv. Manag. 2017, 33, 152-162. [CrossRef]

72. Wang, C.; Liang, J.; Pei, Y.; Wendling, L.A. A Method for Determining the Treatment Dosage of Drinking Water Treatment Residuals for Effective Phosphorus Immobilization in Sediments. Ecol. Eng. 2013, 60, 421-427. [CrossRef]

73. Wang, C.; Wang, Z.; Lin, L.; Tian, B.; Pei, Y. Effect of Low Molecular Weight Organic Acids on Phosphorus Adsorption by Ferric-Alum Water Treatment Residuals. J. Hazard. Mater. 2012, 203-204, 145-150. [CrossRef]

74. Zhang, D.; Kong, H.; Wu, D.; He, S.; Hu, Z.; Dai, L. Impact of Pyrolysis Treatment on Heavy Metals in Sediment. Soil Sediment Contam. Int. J. 2009, 18, 754-765. [CrossRef]

75. Wang, C.; Wei, Z.; Yan, Z.; Wang, C.; Xu, S.; Bai, L.; Jiang, H.; Yuan, N. The Feasibility of Recycling Drinking Water Treatment Residue as Suspended Substrate for the Removal of Excess P and N from Natural Water. J. Environ. Manag. 2021, 280, 111640. [CrossRef]

76. Hoorman, J.; Hone, T.; Sudman, T.; Dirksen, T.; Iles, J.; Islam, K.R. Agricultural Impacts on Lake and Stream Water Quality in Grand Lake St. Marys, Western Ohio. Water Air Soil Pollut. 2008, 193, 309-322. [CrossRef]

77. Yuan, N.; Wang, C.; Pei, Y.; Jiang, H. Applicability of Drinking Water Treatment Residue for Lake Restoration in Relation to Metal/Metalloid Risk Assessment. Sci. Rep. 2016, 6, 38638. [CrossRef] [PubMed]

78. Sotero-Santos, R.B.; Rocha, O.; Povinelli, J. Toxicity of Ferric Chloride Sludge to Aquatic Organisms. Chemosphere 2007, 68, 628-636. [CrossRef]

79. Ranjbar, L.; Eslami, A.; Yazdanbakhsh, A.; Saghi, M.H. Toxicity Assessment of Tehran Water Treatment Sludges Using Bioassay Tests. Toxin Rev. 2018, 37, 27-34. [CrossRef]

80. Yuan, N.; Wang, C.; Wendling, L.A.; Pei, Y. Ecotoxicological Assessment of Dewatered Drinking Water Treatment Residue for Environmental Recycling. Environ. Technol. 2017, 38, 2241-2252. [CrossRef] [PubMed]

81. Yuan, N.; Wang, C.; Pei, Y. Investigation on the Eco-Toxicity of Lake Sediments with the Addition of Drinking Water Treatment Residuals. J. Environ. Sci. 2016, 46, 5-15. [CrossRef]

82. Yuan, N.; Pei, Y.; Bao, A.; Wang, C. The Physiological and Biochemical Responses of Daphnia Magna to Dewatered Drinking Water Treatment Residue. Int. J. Environ. Res. Public Health 2020, 17, 5863. [CrossRef]

83. Devi, P.; Saroha, A.K. Utilization of Sludge Based Adsorbents for the Removal of Various Pollutants: A Review. Sci. Total Environ. 2017, 578, 16-33. [CrossRef] [PubMed]

84. Sørmo, E.; Silvani, L.; Thune, G.; Gerber, H.; Schmidt, H.P.; Smebye, A.B.; Cornelissen, G. Waste Timber Pyrolysis in a MediumScale Unit: Emission Budgets and Biochar Quality. Sci. Total Environ. 2020, 718, 137335. [CrossRef] [PubMed]

85. Lürling, M.; Kang, L.; Mucci, M.; van Oosterhout, F.; Noyma, N.P.; Miranda, M.; Huszar, V.L.M.; Waajen, G.; Marinho, M.M. Coagulation and Precipitation of Cyanobacterial Blooms. Ecol. Eng. 2020, 158, 106032. [CrossRef]

86. Thongdam, S.; Kuster, A.C.; Huser, B.J.; Kuster, A.T. Low Dose Coagulant and Local Soil Ballast Effectively Remove Cyanobacteria (Microcystis) from Tropical Lake Water without Cell Damage. Water 2021, 13, 111. [CrossRef] 